\title{
Fluid-controlled deformation in blueschist-facies conditions: plastic vs brittle behaviour in a brecciated mylonite (Voltri Massif, Western Alps, Italy)
}

\author{
C. MALATESTA*†,L.FEDERICO*,L.CRISPINI* \& G.CAPPONI* \\ *DISTAV, University of Genoa, corso Europa 26, 16132 Genoa, Italy
}

(Received 17 June 2016; accepted 24 November 2016; first published online 25 January 2017)

\begin{abstract}
A blueschist-facies mylonite crops out between two high-pressure tectono-metamorphic oceanic units of the Ligurian Western Alps (NW Italy). This mylonitic metabasite is made up of alternating layers with different grain size and proportions of blueschist-facies minerals.

The mylonitic foliation formed at metamorphic conditions of $T=220-310^{\circ} \mathrm{C}$ and $P=6.5-10 \mathrm{kbar}$. The mylonite shows various superposed structures: (i) intrafoliar and similar folds; (ii) chocolatetablet foliation boudinage; (iii) veins; (iv) breccia.

The occurrence of comparable mineral assemblages along the foliation, in boudin necks, in veins and in breccia cement suggests that the transition from ductile deformation (folds) to brittle deformation (veining and breccia), passing through a brittle-ductile regime (foliation boudinage), occurred gradually, without a substantial change in mineral assemblage and therefore in the overall $P-T$ metamorphic conditions (blueschist-facies).

A strong fluid-rock interaction was associated with all the deformative events affecting the rock: the mylonite shows an enrichment in incompatible elements (i.e. As and Sb), suggesting an input of fluids, released by adjacent high-pressure metasedimentary rocks, during ductile deformation. The following fracturing was probably enhanced by brittle instabilities arising from strain and pore-fluid pressure partitioning between adjacent domains, without further external fluid input.

Fluids were therefore fixed inside the rock during mylonitization and later released into a dense fracture mesh that allowed them to migrate through the mylonitic horizon close to the plate interface.

We finally propose that the fracture mesh might represent the field evidence of past episodic tremors or 'slow earthquakes' triggered by high pore-fluid pressure.
\end{abstract}

Keywords: mylonite, fluids, ductile-brittle transition, blueschist metamorphism, foliation boudinage, Western Alps, slow earthquakes.

\section{Introduction}

Fluids are a key component in subduction zones, promoting the transfer of chemical elements from the subducting slab to volcanic arcs, influencing metamorphic reactions and deformation of rocks, and potentially triggering tremors or intra-slab earthquakes (Hacker et al. 2003; Bebout, 2007; John et al. 2008; Audet et al. 2010). The correlations between fluids and veins in subduction zones at high-pressure conditions have been widely studied in eclogite-facies rocks (e.g. Philippot \& Selverstone, 1991; Scambelluri et al. 1991; Gao \& Klemd, 2001; John et al. 2008; Spandler, Pettke \& Rubatto, 2011; Angiboust et al. 2014). These veins formed by locally derived fluids or by episodic infiltration of highly channelized external fluids (Philippot \& Selverstone, 1991; Rubatto \& Hermann, 2003; John et al. 2008; Angiboust et al. 2014); the last process probably takes advantage of extensive, interconnected vein networks or lithologic contacts, where mechanical weaknesses between differing lithologies may cause enhanced permeability and facilitate fluid flow

†Author for correspondence: cristina.malatesta@unige.it
(Breeding et al. 2003; Angiboust et al. 2014). As a consequence, most high-pressure rocks undergo fracturing either because of their dehydration after increase in metamorphic conditions (i.e. blueschist to eclogite transition) or because of incoming fluids released by other lithologies (e.g. John et al. 2008). Philippot \& Selverstone (1991), observing a foliated eclogitic metagabbro in the Monviso ophiolitic complex (Western Alps), concluded that a continuous fluid-assisted interaction between ductile and brittle deformation affected the metagabbro body and pulses of fluids were associated in time with increments of shear and tensile failure.

Large-scale fluid pathways have been observed both along the subduction interface and inside the slab itself (Bebout \& Barton, 1989; Breeding, Ague \& Bröcker, 2004; Angiboust \& Agard, 2010; Angiboust et al. 2014; Scambelluri et al. 2014, 2016; Bebout \& Penniston-Dorland, 2016). Experimental studies indicate that some fluids are released from the subducting slab through discontinuous or continuous reactions at almost any depths in the range $70-300 \mathrm{~km}$ (Peacock, 1993; Schmidt \& Poli, 1998; Ulmer \& Trommsdorff, 1999); the major pulse of fluid release from 
the oceanic crust occurs at $c .50-70 \mathrm{~km}$ depth (Peacock, 1993; Schmidt \& Poli, 1998), whereas at shallow depths $(<15 \mathrm{~km})$ most of the fluids are expelled through porosity collapse and diagenesis, and collected via large fault systems (Le Pichon, Henry \& Lallemant, 1990; Moore \& Vrolijk,1992). Thermodynamic studies indicate that along an average geotherm $\left(6^{\circ} \mathrm{C} \mathrm{km}^{-1}\right)$ characterizing present-day subduction zones, $\mathrm{H}_{2} \mathrm{O}$ release from subducted sediments is concentrated in a depth range of $c .70-100 \mathrm{~km}$ and metabasalts mostly dehydrate at depths of $80-120 \mathrm{~km}$ (Li et al. 2008).

Despite these numerous studies, some open questions still remain about the mechanisms of release, infiltration and migration of fluids through the slabmantle interface and inside the slab (Breeding et al. 2003; John et al. 2008; Angiboust et al. 2014): how are fluids extracted and concentrated in the rocks, leading to infiltration towards the overriding plate, mobilizing chemical elements? what is the origin of fluids migrating along the slab and what is the length scale of the fluid flow? in what way is fluid circulation correlated with deformation under high-pressure conditions?

In this paper, we present the study of a blueschist mylonitic body that occurs at the contact between two metamorphic ophiolitic units: the blueschist Montenotte Unit and the eclogitic Voltri Unit (Ligurian Western Alps; Federico et al. 2014). The blueschist mylonitic metabasite (hereafter MM) was affected by complex deformations, evolving from ductile (i.e. folding) to brittle-pervasive veining and brecciation at relatively constant $P-T$ conditions. The body was permeated by fluids expelled by metasediments during ductile deformation, whereas fracturing was triggered by internal fluids.

The aim of this paper is:

(i) to describe the structural and petrographic features of the MM, with $P-T$ determinations of climax metamorphism via $P-T$ pseudosection computation;

(ii) to discuss the progressive deformation of the $\mathrm{MM}$ and the role of fluids influencing the plastic vs brittle behaviour of rocks, including the possible relations with seismicity;

(iii) to discuss such structural and metamorphic evolution in the framework of the alpine subduction and the provenance of fluids.

\section{Geological setting}

The study area is located at the limit between two tectono-metamorphic units: the Montenotte and Voltri units (Capponi et al. 2013, 2015; Federico et al. 2014). The two units pertain to the internal LigurianPiedmontese domain of the Western Alps (Fig. 1) (Vanossi et al. 1984); they represent a fragment of the Mesozoic Ligurian-Piedmontese ocean subducted during Cretaceous to Eocene time below the Apulian margin; the continental collision between Europe and
Adria during the Middle Eocene led to the building of the Western Alpine chain and to the present architecture of the study area (e.g. Vanossi et al. 1984; Polino, Dal Piaz \& Gosso, 1990; Ford, Duchêne \& Gasquet, 2006).

Both the Montenotte and Voltri units pertain to the Voltri Massif which has been interpreted as a fossil plate-interface domain now exposed to the surface (Federico et al. 2007; Malatesta et al. 2012b; Scambelluri \& Tonarini, 2012; Scambelluri et al. 2016).

\section{2.a. The Montenotte Unit}

The Montenotte Unit crops out in the central-western part of Liguria, W-SW of the Voltri Unit (Figs 1, 2); it encompasses a metamorphosed ophiolitic succession, made up of predominant metagabbro (both Feand Ti-oxide-rich and $\mathrm{Mg}$-rich varieties), metabasalt and serpentinite, plus the metamorphosed sedimentary cover comprising metachert, meta-limestone and phylladic schist. The metamorphic stage in blueschistfacies conditions (Table 1a) produces an assemblage of albite + chlorite + Na-amphibole \pm Na-pyroxene \pm lawsonite \pm pumpellyite \pm epidote in metagabbro (Cabella et al. 1994; Cortesogno et al. 2002; Capponi et al. 2013), pointing to conditions of $c .1 .1 \mathrm{GPa}$ and $340 \pm 20^{\circ} \mathrm{C}$ (Desmons, Compagnoni \& Cortesogno, 1999 and references therein). Late greenschist-facies overprint occurs in places and is mainly detectable in the Fe- and Ti-oxide-rich metagabbros, with actinolite and albite blastesis (Federico et al. 2014).

From the structural point of view, the Montenotte Unit is characterized by two folding phases coeval with the blueschist-facies metamorphism $\left(\mathrm{D}_{1}\right.$ and $\mathrm{D}_{2}$, Table 1a; Beccaluva et al. 1979; Anfossi, Colella \& Messiga, 1984; Capponi et al. 2013). The $\mathrm{D}_{1}+\mathrm{D}_{2}$ folding gives rise to Type 3 interference patterns (Ramsay $\&$ Huber, 1987), traceable up to the map scale in the study area (Fig. 2; Federico et al. 2014). The most evident foliation in the field is commonly a composite fabric that contains the $\mathrm{D}_{1}$ - and $\mathrm{D}_{2}$-related schistosities, and which in this area is mainly NW-SE striking; such composite fabric controls the contacts among lithologies.

A later phase of open to gentle, sub-cylindrical folding, with rare axial plane cleavages $\left(\mathrm{D}_{3}\right.$; Beccaluva et al. 1979; Anfossi, Colella \& Messiga, 1984; Capponi et al. 2013), is coeval with low greenschist-facies metamorphic conditions (Capponi et al. 2013) and is shared with the Voltri Unit (Federico et al. 2014).

Contractional structures of Aquitanian - early Burdigalian age are represented by long-wavelength open folds and thrusts $\left(\mathrm{D}_{4}\right.$ of Capponi \& Crispini, 2002), with top-to-the-E-NE vergence. This phase is shared with the Voltri Unit (Federico et al. 2014).

\section{2.b. The Voltri Unit}

The Voltri Unit (Capponi \& Crispini, 2008; Capponi et al. 2015) crops out at the southeastern termination 


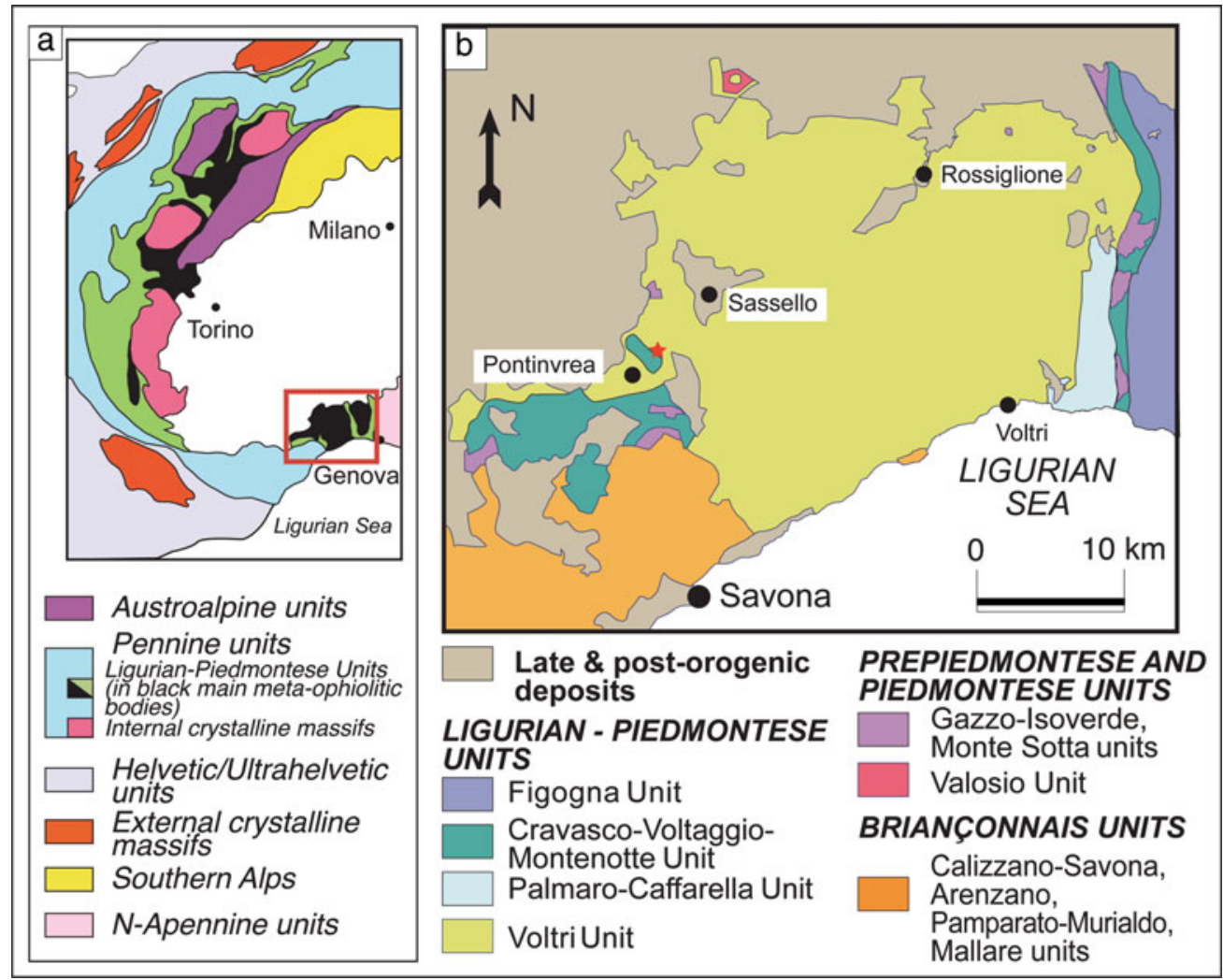

Figure 1. (Colour online) (a) Sketch of the NW Alps (box locates area of (b)); (b) Simplified geological map of the easternmost Ligurian Alps (red star locates the studied outcrop).

Table 1. Synoptic table summarizing the metamorphic and deformative events in (a) the Montenotte and (b) Voltri units (modified after Federico et al. 2014), and in (c) the studied mylonite outcrop in between (this work).

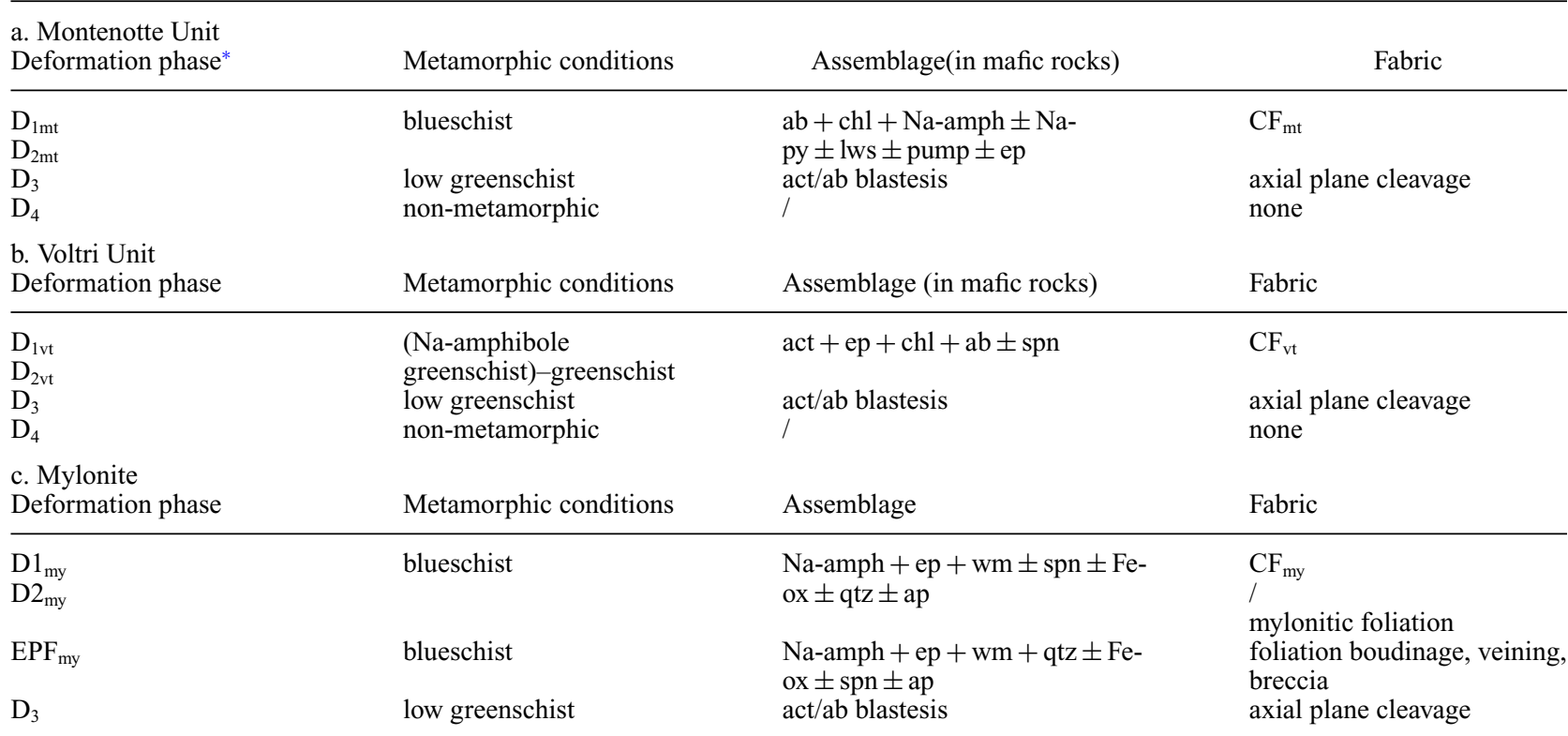

*Subscripts 'mt', 'vt' and 'my' refer to 'Montenotte', 'Voltri' and 'mylonite' respectively. In the mylonite outcrop the concentration of deformation triggered the development of a peculiar structural evolution, possibly independent of the adjoining rocks; as a result, $\mathrm{D}_{1 \mathrm{my}}$ and $\mathrm{D}_{2 \mathrm{my}}$ folds have no direct correlation with $\mathrm{D}_{1 \mathrm{mt}}$ and $\mathrm{D}_{2 \mathrm{mt}}$ folds of the Montenotte Unit, albeit developed under the same blueschist facies metamorphic conditions (Federico et al. 2014).

of the Western Alps, E-NE of the Montenotte Unit (Fig. 1b). It includes metamorphic ophiolitic rocks with metasediments and slices of subcontinental lithospheric mantle (Chiesa et al. 1975; Piccardo, 1977; Rampone et al. 2005). Meta-ophiolites are serpent- inite, metagabbro and metabasite, and are associated with calcschist, minor mica- and quartz-schist; mantle rocks encompass lherzolite and harzburgite with minor pyroxenite and dunite. The Voltri Unit re-equilibrated at peak eclogite-facies conditions, with the growth 


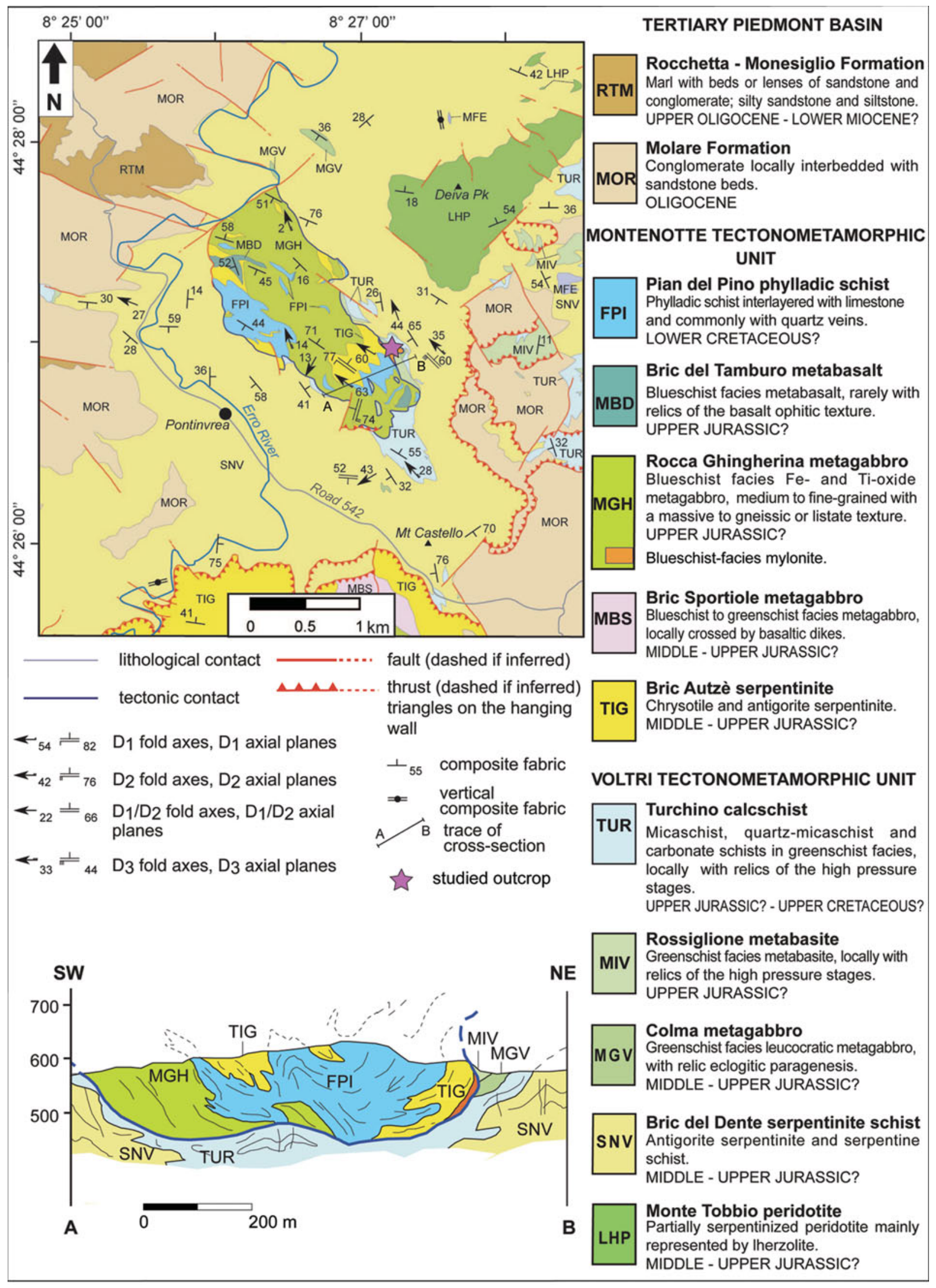

Figure 2. (Colour online) Geological map and cross-section of the study area (star locates the studied outcrop). The Montenotte and Voltri units and the mylonite at the contact are all deformed by a regional-scale $\mathrm{D}_{3}$ fold with NW-SE-trending, NW-plunging axis. 
of garnet + omphacite + rutile + Na-amphibole \pm phengite \pm clinozoisite in Fe-rich metagabbro (e.g. Ernst, 1976; Bocchio, 1995), corresponding to metamorphic conditions of $P=18-22 \mathrm{kbar}$ and $T=500-600^{\circ} \mathrm{C}$ (e.g. Messiga, Piccardo \& Ernst, 1983; Liou et al. 1998; Brouwer, Vissers \& Lamb, 2002; Federico et al. 2004) achieved at c. $50 \mathrm{Ma}(\mathrm{Fe}-$ derico et al. 2005). A later partial re-equilibration in greenschist-facies conditions affected the Voltri Unit during the Early Oligocene (Federico et al. 2005) and is particularly pervasive in metasedimentary rocks.

Several deformational events have been described in this unit (Table 1b; Vanossi et al. 1984; Capponi \& Crispini, 2002, 2008; Malatesta et al. 2012a): the oldest structures are eclogite-facies foliation and rootless hinges of isoclinal folds, which have no continuity across outcrops. The most pervasive structures are tight to isoclinal transpositive $D_{1}$ and $D_{2}$ folds, developed in metamorphic conditions ranging from Na-amphibole greenschist facies to greenschist facies sensu stricto (Crispini \& Frezzotti, 1998; Capponi \& Crispini, 2002). Their superposition gives rise to a Type 3 interference pattern (Ramsay \& Huber, 1987), and the superposition of $\mathrm{D}_{1}$ and $\mathrm{D}_{2}$ schistosities produces a Composite Fabric that controls contacts among different lithologies.

The later $\mathrm{D}_{3}$ event is shared with the Montenotte Unit and is coeval with low greenschist-facies metamorphic conditions. $F_{3}$ folds are usually parallel folds, gentle to open in shape, in places associated with a roughly spaced cleavage.

The $\mathrm{D}_{4}$ event is also shared with the Montenotte Unit (Federico et al. 2014) and is expressed by longwavelength open folds and thrusts, with top-to-the-ENE vergence.

\section{Structural and petrographic data of the mylonite outcrop}

The studied MM crops out (Fig. 3) between the Montenotte Unit serpentinite (to the west) and the metasediment/metabasite of the Voltri Unit (to the east); here metasediment and metabasite are interbedded, with $\mathrm{cm}$-thick talcschist layers in between.

The MM is characterized by alternating fine-grained and minor ultra-fine-grained domains $(c .10 \mathrm{~cm}$ thick). The variations in grain size can potentially be either an inherited original feature later enhanced by deformation (i.e. presence of basaltic dykes and/or pillows) or a result of the mylonitization processes.

As described in the following paragraphs, we observed several superposed structures formed at the same metamorphic conditions: this indicates that the MM underwent a progressive polyphase deformation history (Figs 4, 5a; Table 1c).

\section{3.a. Ductile and brittle/ductile structures}

\section{3.a.1. Folds and schistosities}

The oldest deformative event is represented by $\mathrm{mm}$ size intrafoliar folds $\left(\mathrm{D}_{1}\right.$ folds; Fig. 6a) and rootless

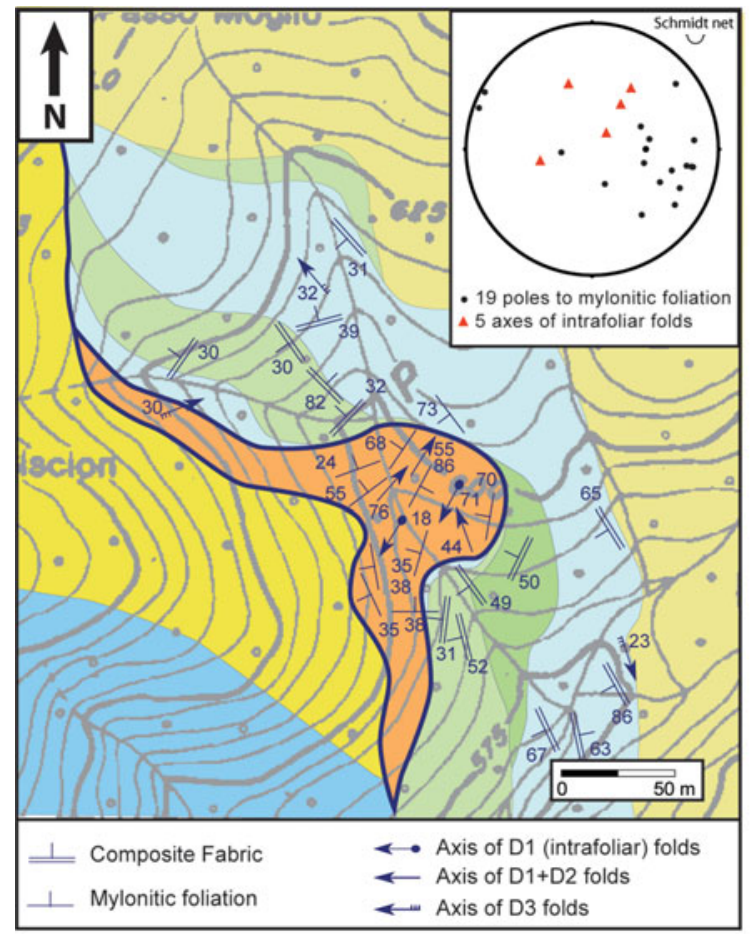

Figure 3. (Colour online) Detailed geological map of the study area (for colour legend see Fig. 2); the equal-area stereoplot shows the attitude of main structural features in the MM.

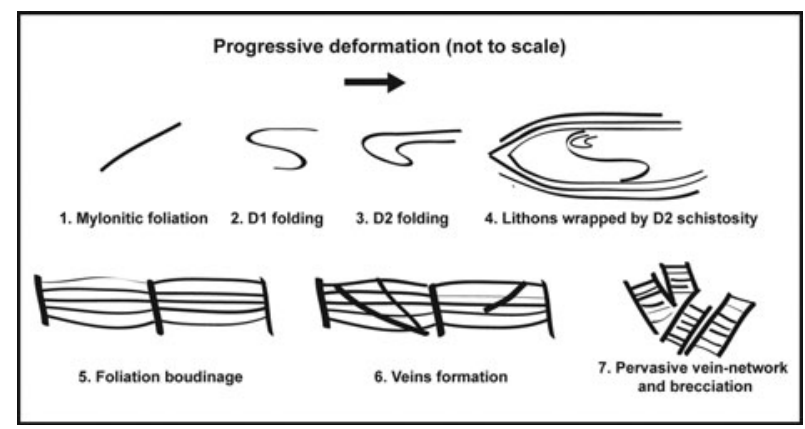

Figure 4. Sketch showing the structures formed by the progressive deformation of the MM.

hinges of folds that deform a fine-grained blueschist mylonitic foliation; $\mathrm{D}_{1}$ folds are associated with a Naamphibole-bearing axial plane schistosity. These folds and the related schistosity are deformed by moderately non-cylindrical tight similar folds $\left(\mathrm{D}_{2}\right.$ folds $)$ of $\mathrm{mm}$ to $\mathrm{cm}$ size (Fig. 5a, b); the axes of such folds have a pitch of $60-80^{\circ}$ on the axial plane (similar to the 'reclined folds' of Ghosh \& Sengupta, 1987).

The schistosity associated with the $\mathrm{D}_{2}$ event is pervasive and the related transposition is severe: lithons in which $\mathrm{D}_{1}$ and $\mathrm{D}_{2}$ folds are visible (Fig. $5 \mathrm{~b}$ ) are preserved only locally. In such domains, the superposition of $D_{1}$ and $D_{2}$ folds gives rise to Type 3 interference patterns (Ramsay \& Huber, 1987). In most cases the superposition of $\mathrm{D}_{1}$ - and $\mathrm{D}_{2}$-related schistosities and the former mylonitic foliation results in a Composite Fabric ( $\mathrm{CF}$, corresponding to the mylonitic foliation) that 

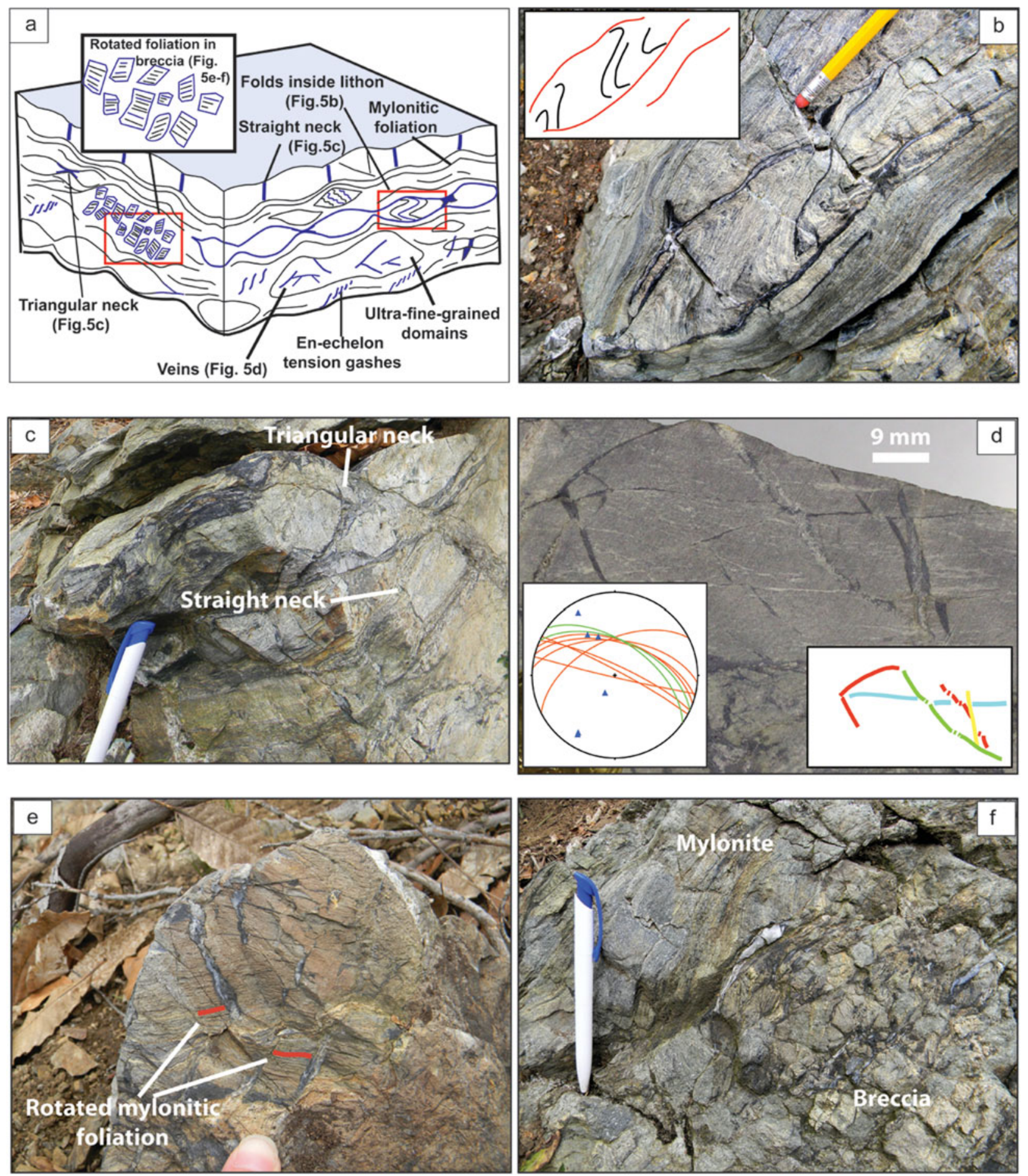

Figure 5. (Colour online) (a) A 3D sketch showing the geometrical relationships between structural elements (see text for description); (b) isoclinal folds preserved in lithons (note the blue-amphibole-rich surfaces); (c) boudins with different neck geometries; (d) several generations of veins cross-cutting the hand specimen; the attitudes of vein set 1 (red line) and 2 (green line) are shown in the equal-area stereoplot together with boudin axes (triangles); in the sketch, light-blue line is a Na-amphibole-rich surface, red lines are vein set 1, yellow line is vein set 2 and green line is vein set 3; (e) breccia with veins cutting at high angle the foliation; red lines show the trace of the rotated mylonitic foliation inside different clasts; (f) brecciated domain in contact with unbrecciated MM.

is the most evident structure in the field (Fig. 3). Along the CF we observed asymmetric porphyroclasts, either bluish or whitish, with either a $\sigma$ or $\delta$ geometry.

In fine-grained domains (M1M2, M1M4 samples) both the main foliation (composite fabric) and the folded foliation, preserved inside lithons, show alternating sub-mm-thick layers respectively rich in (i) $\mathrm{Na}$ - amphibole, (ii) epidote, (iii) white mica + epidote and (iv) Fe-oxide (Figs 6b, 7a):

(i) Na-amphibole-rich layers are made by $\mathrm{Na}-$ amphibole + minor white mica, Fe-oxides and quartz growing syn-kinematically; Na-amphibole, classified as glaucophane or Mg-riebeckite according to Leake et al. (1997) (Fig. 8a), locally replaces as aggregates 

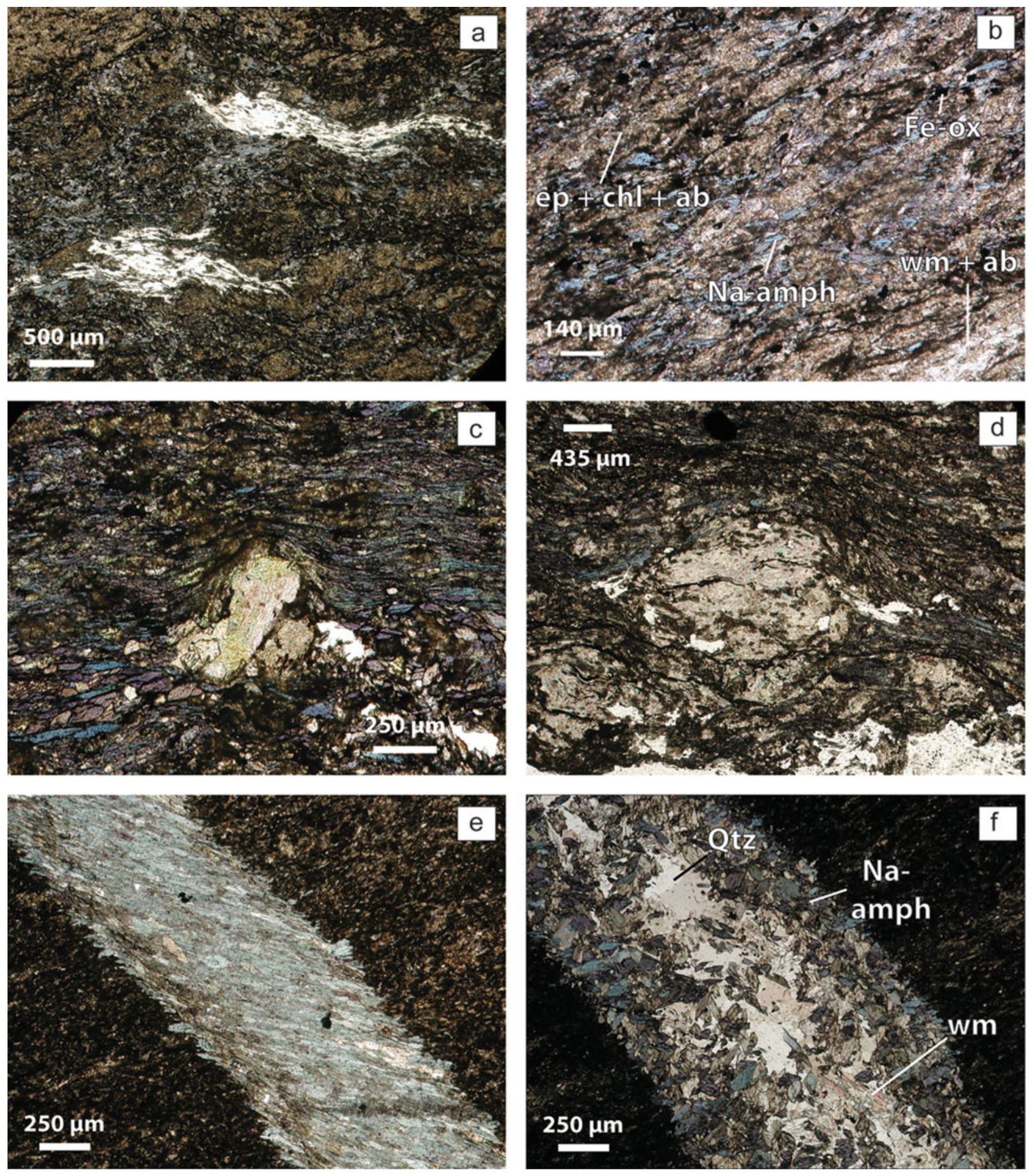

Figure 6. (Colour online) Thin-section photomicrograph. (a) Stretched hinges of intrafoliar folds (fine-grained white mica). Folds developed a pervasive axial plane schistosity and Na-amphibole grew; (b) mylonitic foliation; (c, d) phengite/paragonite + clinozoisite + chlorite pseudomorphs after lawsonite; (e) syntaxial shear vein including Na-amphibole fibres; (f) composite vein.

porphyroclasts occurring along the main foliation. White mica has a phengitic composition and shows large variations of Si content (from 6.11 to 6.86 Si per formula unit (pfu)) (Fig. 8b), with Si content decreasing from cores to rims. The highest $\mathrm{Si}$ content is in phengite along the former folded foliation preserved in lithons (M1M4 sample).

(ii) Epidote-rich layers are often cloudy and include fine-grained syn-kinematic epidote + white mica + minor Na-amphibole + sphene + apatite
+ tiny spinels. The chemical composition of epidote varies between the clinozoisite and the $\mathrm{Fe}$ rich epidote end-members; clinozoisite is gradually overgrown by Fe-rich epidote, with $\mathrm{Fe}$ content increasing from the core to the rim of the crystal. Quartz grows between Na-amphiboles replacing epidote. Locally aggregates of Na-amphibole + epidote or white mica + minor epidote pseudomorphose former porphyroclasts ( $\sigma$ - and $\delta$-type porphyroclasts), respectively sigmoidal- and rounded/prismatic-shaped 

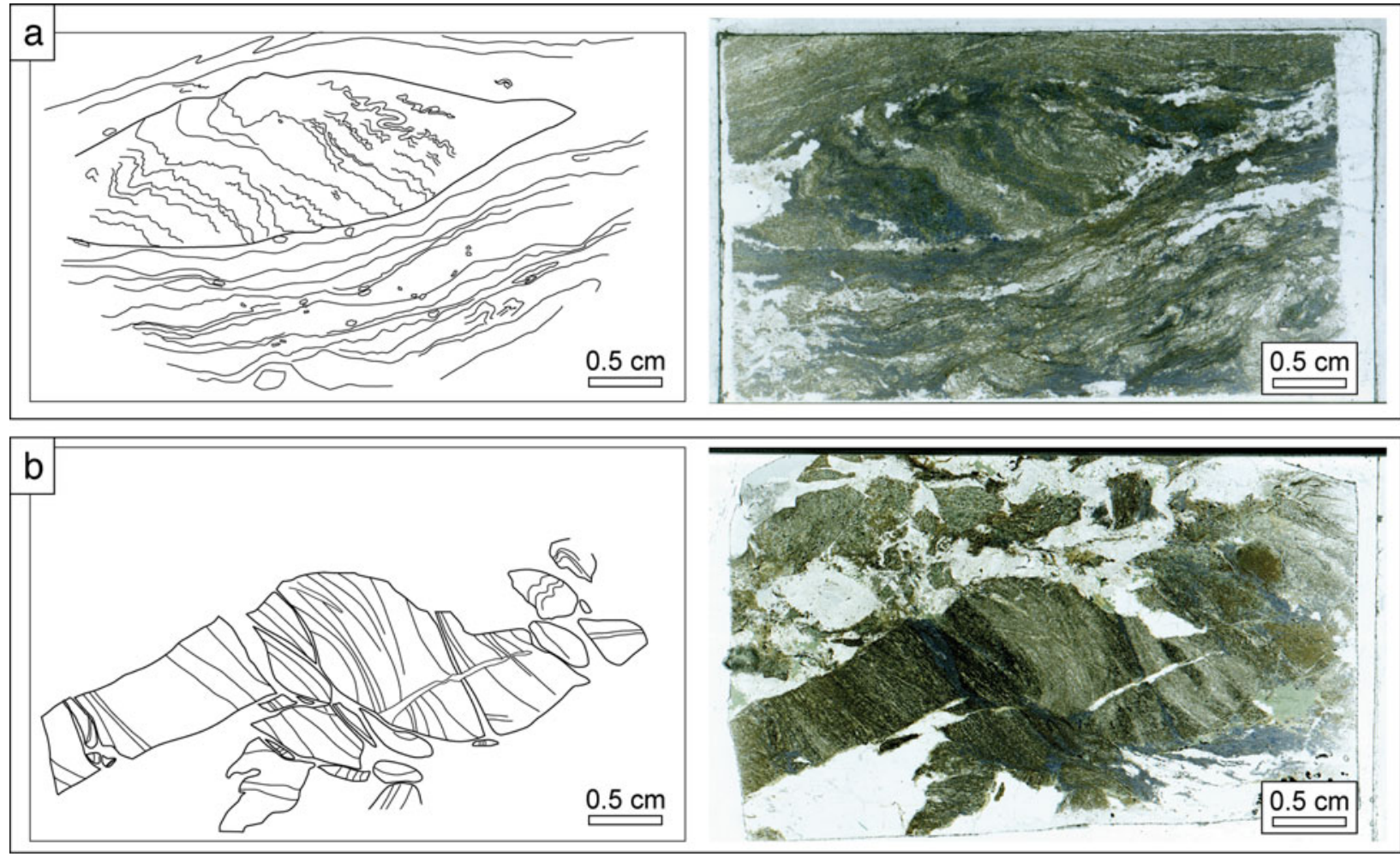

Figure 7. (Colour online) Scan of thin section (right) and its redrawing (left): (a) sample M1M4 shows the folded foliation inside a microlithon wrapped by the main mylonitic foliation; rounded pseudomorphoses on former lawsonite, now made up of fine-grained white-mica \pm minor epidote occur along the main foliation; (b) sample M1M9 shows different breccia clasts with an internal mylonitic foliation (more recent albite-rich veining in the upper left part of the thin section has been omitted for simplicity).
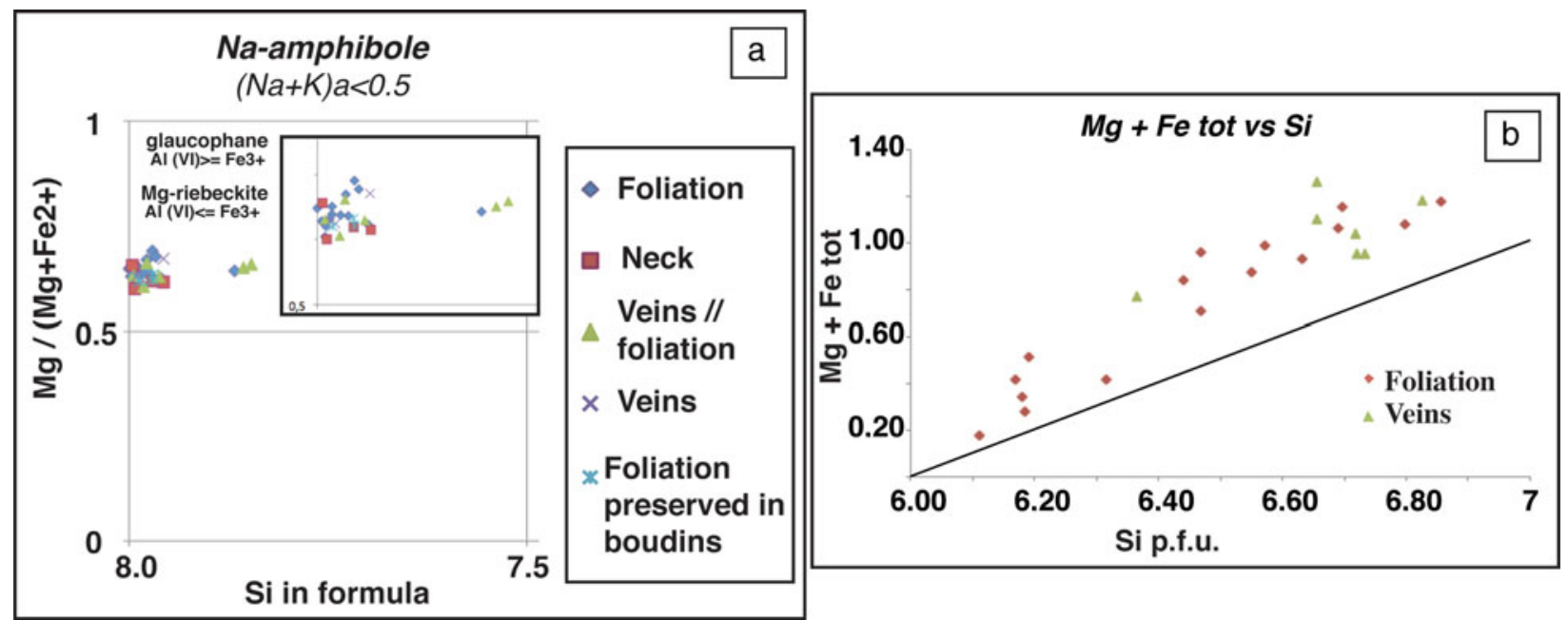

Figure 8. (Colour online) Na-amphibole and white mica composition. (a) Classification diagram of Na-amphibole after Leake et al. (1997); (b) white mica ( $\left.\mathrm{Mg}+\mathrm{Fe}_{\text {tot }}\right)$ vs Si diagram.

(Fig. 6c, d); porphyroclasts show syn-kinematic Naamphibole antitaxial strain fringes (Fig. 6d). White mica-rich porphyroclasts often occur along the boundary of mm-size lithons (Fig. 7a), and locally preserve Fe-oxide layers concordant with oxide layers along the main foliation (Fig. 6c, d). White mica includes tiny crystals of epidote and zircon; in pseudomorphoses it is classified as phengite/paragonite; here phengite has the lowest $\mathrm{Si}$ value (6.11-6.19 Si pfu). (iii) Fine-grained syn-kinematic white mica + epidote + rare sphene, Na-amphibole and Fe-oxides occur in white mica-rich whitish layers. Here sphene includes micron-size rutile crystals.

(iv) Fe-oxide-rich layers wrap white mica porphyroclasts occurring along the main foliation. Rare tiny sulphides occur.

Ultra-fine-grained domains (M1M3 and M1M9 samples) have a cloudy texture with a pervasive foliation outlined by layers of (i) Na-amphibole + minor 


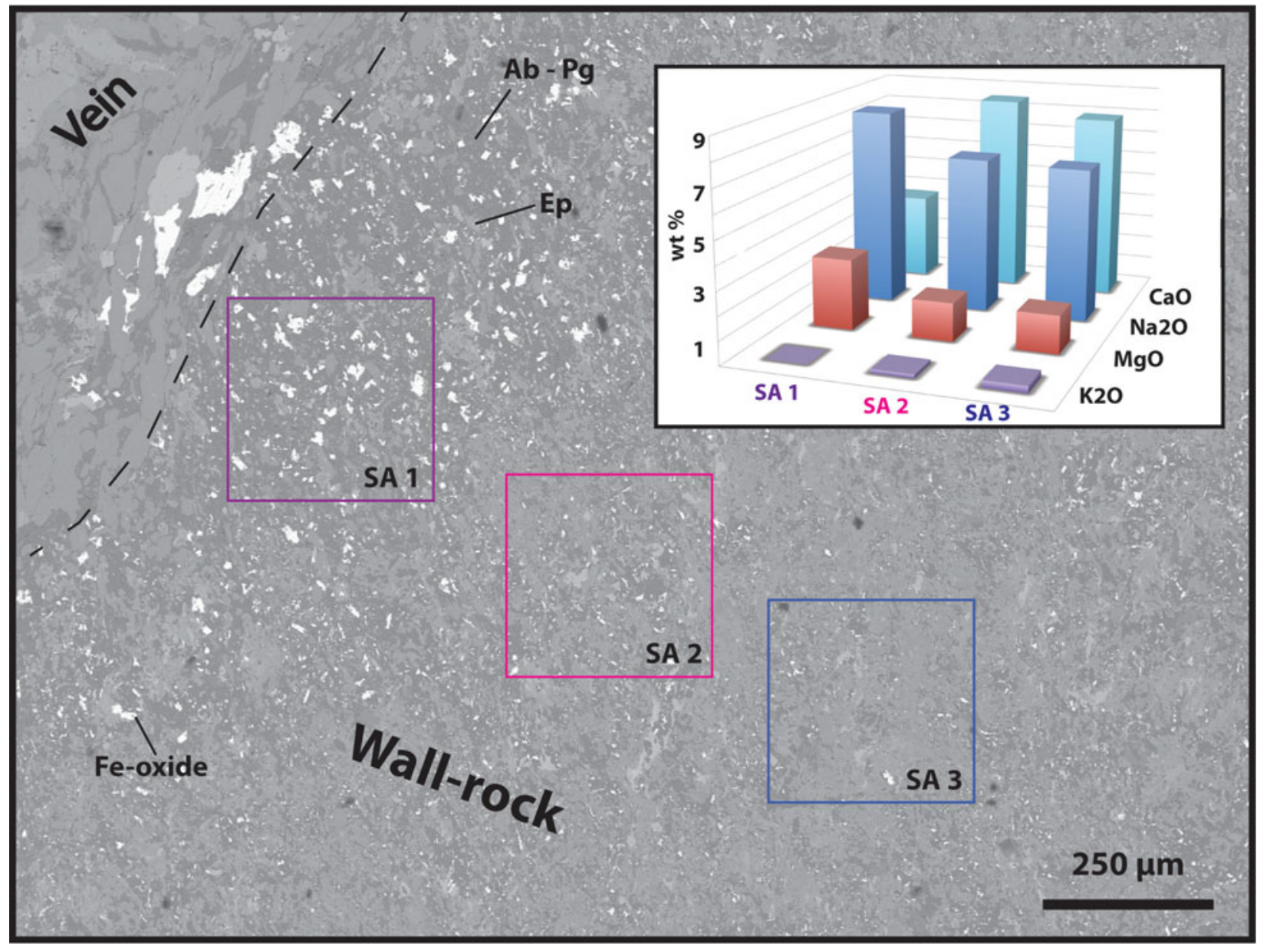

Figure 9. (Colour online) Electron microprobe image and chemical variation of selected areas in the wall rock at different distances from the vein. The mineral abbreviations are after Kretz (1983).

white mica, sphene and apatite; (ii) epidote + white mica + sphene+ Ti-V-bearing Fe-oxide-hydroxide + minor Na-amphibole and apatite - rare tiny sulphides occur; and (iii) syn-kinematic fine-grained epidote + fluoro-apatite + minor white mica (whitish layers). Here white mica has been classified as phengite and paragonite; paragonite is syn- to post-epidote, and is overgrown by albite.

Both in fine- and ultra-fine-grained domains, minor chlorite grows between oxides and epidote replacing them. Finally fine-grained albite grows, replacing chlorite, epidote, white mica and locally Naamphibole. Fe-oxides (haematite), growing together with albite, replace Na-amphibole. Locally, white mica and quartz grow on epidote.

Along the foliation of these two domains, aggregates of either fine-grained (1) Na-amphibole or (2) Na-amphibole + epidote occur, developing $\mathrm{Na}$ amphibole fringes. We interpret aggregates (1) and (2) as pseudomorphoses after pre- to syn-kinematic pyroxene.

The pseudomorphoses made of phengite/paragonite + epidote or uniquely of phengite aggregates could be interpreted as lawsonite (see Faryad \& Hoinkes 1999; Able \& Brady, 2001), thus indicating that at least the mylonitic foliation formed in lawsonite-blueschist facies metamorphic conditions; when $P-T$ conditions changed, lawsonite broke down.

\section{3.a.2. Foliation boudinage}

A later foliation boudinage (Fig. 5c) affects the composite fabric, and generates boudins visible from the $\mathrm{mm}$ to the outcrop scale, wrapped by $\mathrm{Na}$ amphibole-rich surfaces (syn-kinematic Na-amphibole fibres + minor epidote and fine-grained sphene or Naamphibole + minor white mica + apatite + rare Feoxides + tiny sphene replacing rutile), which mark the transition to the main mylonitic foliation.

Boudinage has a dominantly symmetric chocolatetablet structure (Fig. 5a) with a minor asymmetric component, suggested by Na-amphibole-bearing en échelon tension gashes. Boudin necks, often joining up with Na-amphibole-rich surfaces wrapping them, are filled by syn-kinematic Na-amphibole or Naamphibole + quartz; they are commonly straight-type necks, but in places they show more complex geometries, i.e. lozenge-shaped, triangular or crescent type (Arslan, Passchier \& Koehn, 2008; Fig. 5c) or are represented by tension gashes. Locally the centre of the necking zone hosts an association of syn-kinematic chlorite + sphene + epidote + prismatic oxides + 
apatite + minor Na-amphibole + minor albite. Here chlorite is syn- to post- Na-amphibole.

\section{3.b. Brittle structures}

\section{3.b.1. Veins}

Several sets of veins cut, at a high angle, the mylonitic foliation. We numbered the vein sets from 1 to 5 based on the vein cross-cutting relationships, vein set 1 being the oldest (Fig. 5d). Sets 1 to 3 are syntaxial shear to composite veins and include blueschistfacies assemblages (Fig. 6e, f); sets 4 and 5 are composite veins and developed under later greenschistfacies conditions (see online Supplementary Material, available at http://journals.cambridge.org/10.1017/ S0016756816001163, and Table S1 therein for a detailed petrographic description).

Vein sets 1 and 2 contain either abundant Naamphibole + minor epidote and sphene (vein set 1$)$ or Na-amphibole + quartz + white mica + apatite (vein set 2), respectively; both the comparable mineralogical content of boudin necks and vein set 1 , and the consistency between the direction of extension indicated by vein set 1 and boudins (Fig. 5d) suggest that the described veining is coeval with boudinage.

We focused in particular on vein set 3 , which shows a first opening stage with syn-kinematic Na-amphibole fibres + minor epidote + haematite, followed by albite + epidote + Na-amphibole + white mica + apatite + haematite growth during a second opening stage. We observed that in the wall rock, approaching these veins, albite and Fe-oxide content greatly increases, replacing epidote and Na-amphibole (Fig. 9). Postkinematic prismatic tiny white mica (paragonite) occurs, partially replaced by albite. This mineralogical variation is reflected by the increase of $\mathrm{Na}, \mathrm{Mg}$ and $\mathrm{Si}$, and by decreasing $\mathrm{Ca}$ and $\mathrm{K}$, moving towards the vein wall. The chemical variation approaching the vein suggests that the wall rock interacted with a fluid that enriched it in $\mathrm{Na}, \mathrm{Mg}$ and $\mathrm{Si}$ and incorporated $\mathrm{K}$ and $\mathrm{Ca}$.

\section{3.b.2. Breccia}

In some limited horizons and pods, the Na-amphibolebearing vein network becomes more pervasive and the boudins are progressively disrupted up to brecciation. Such breccia is characterized by clasts of the enclosing MM, with size ranging from $<1 \mathrm{~cm}$ to a few $\mathrm{cm}$, often sub-rectangular in shape. The breccia is clast-supported, and exhibits angular clasts, with a high clast/matrix ratio; clasts are cemented by interclast syn-kinematic Na-amphibole and display a small degree of rotation, attested by the variability in attitude of mylonitic foliation in the different fragments (Fig. 5e, f).

Finally, all the described structures have been deformed and reoriented by later low greenschist-facies
$\mathrm{D}_{3}$ folds acting at a regional scale (as visible in Fig. 2; Table 1c).

\section{Bulk-rock composition}

In order to obtain updated $P-T$ determinations on the metamorphic conditions, we planned an approach based on the pseudosection method. For the set-up of the method, data on the bulk rock composition and on the mineral chemistry are needed (full details are available in the Supplementary Material).

Bulk-rock composition of both fine-grained (M1M2 sample) and ultra-fine-grained domains (M1M3 sample) has been determined by ICP-MS (inductively coupled plasma mass spectrometry) and INAA (instrumental neutron activation analysis) analyses at Activation Laboratories Ltd (Ontario, Canada) (Table 2; Table S2 in Supplementary Material).

We compared our results with worldwide midocean ridge basalt (MORB) and oceanic gabbro majorelement compositions derived from the online PetDB database (http://www.earthchem.org/petdb). The analysed samples display variable loss on ignition (LOI) contents, ranging between 1.87 (ultra-fine-grained domains) and $3.51 \mathrm{wt} \%$ (fine-grained domains). Major elements have a general MORB affinity, and both samples also fall into the field of oceanic gabbros (Fig. S1, online Supplementary Material at http://journals. cambridge.org/10.1017/S0016756816001163). Majorelement composition is also comparable to metabasite and meta Fe-gabbro both of the Montenotte and Voltri units (this work; Piccardo, 1977 and references therein; Liou et al. 1998; L. Federico, unpub. Ph.D. thesis, Univ. Genova, 2003). Fine- and ultrafine-grained samples, however, display a lower $\mathrm{MgO}$ content, and ultra-fine-grained MM also has a higher $\mathrm{Na}_{2} \mathrm{O}$ content.

Rare earth elements (REE), normalized to the chondrite composition (Anders \& Ebihara, 1982), are enriched in both samples, with an almost flat pattern and no significant anomalies (Fig. S2 in Supplementary Material). The REE patterns fall into the field of metabasite and eclogite of the Voltri Massif (R. Tribuzio, unpub. Ph.D. thesis, Univ. Pavia, 1992; L. Federico, unpub. Ph.D. thesis, Univ. Genova, 2003), but are mostly comparable to flat patterns of basalts of the northern Apennines (Internal Liguride) which represent the equivalent of the Montenotte and Voltri units metabasite escaped from deep subduction (Rampone, Hofmann \& Raczek, 1998).

Figure 10 shows that $\mathrm{As}$ and $\mathrm{Sb}$, which are incompatible, fluid-soluble elements, are strongly enriched compared to a MORB composition.

$\mathrm{Nb} / \mathrm{U}$ vs $\mathrm{U}$ and $\mathrm{Th} / \mathrm{U}$ vs Th diagrams highlight both a $U$ gain and a Th loss compared to fresh MORB (Fig. S3 in Supplementary Material), showing that our samples are in accordance with a seafloor alteration trend as defined for a set of altered oceanic crust rocks and metabasalts (Bebout, 2007 and references therein); our MM thus retained these elements (i.e. U) down to 
Table 2. Bulk-rock composition (major elements) of the studied MM and of representative samples of the Montenotte and Voltri units.

\begin{tabular}{|c|c|c|c|c|c|c|c|c|}
\hline & Detection limit & $\begin{array}{c}\text { M1M2 } \\
\text { MM } \\
(w t \%)\end{array}$ & $\begin{array}{c}\text { M1M3B } \\
\text { MM } \\
(w t \%)\end{array}$ & $\begin{array}{c}260511 \text { TV8TV9 } \\
\text { Metabasalt (MU) } \\
(\mathrm{wt} \%)\end{array}$ & $\begin{array}{c}140411 \text { FP4FP1 } \\
\text { Metagabbro (MU) } \\
(\text { wt } \%)\end{array}$ & $\begin{array}{c}070911 \text { TV7TV3 } \\
\text { Phyllade (MU) } \\
\text { (wt \%) }\end{array}$ & $\begin{array}{c}\text { SP5 } \\
\underset{(\text { wt } \%)}{\text { Metagabbro (VU) }}\end{array}$ & $\begin{array}{c}120511 \text { TV6TV3 } \\
\text { Metabasite (VU) } \\
\text { (wt } \%)\end{array}$ \\
\hline $\mathrm{SiO}_{2}$ & 0.01 & 49.42 & 48.5 & 50.2 & 46.06 & 33.47 & 47.11 & 50.67 \\
\hline $\mathrm{Al}_{2} \mathrm{O}_{3}$ & 0.01 & 15.39 & 17.07 & 14.48 & 10.36 & 9.88 & 12.89 & 14.88 \\
\hline $\mathrm{Fe}_{2} \mathrm{O}_{3}(\mathrm{~T})$ & 0.01 & 13.32 & 12.53 & 10.47 & 17.99 & 6.41 & 14.57 & 10.3 \\
\hline $\mathrm{MnO}$ & 0.001 & 0.39 & 0.112 & 0.144 & 0.226 & 0.096 & 0.298 & 0.125 \\
\hline $\mathrm{MgO}$ & 0.01 & 4.14 & 2.36 & 5.36 & 5.91 & 2.68 & 5.27 & 6.51 \\
\hline $\mathrm{CaO}$ & 0.01 & 9.11 & 8.9 & 9.12 & 7.01 & 22.69 & 9.76 & 6.9 \\
\hline $\mathrm{Na}_{2} \mathrm{O}$ & 0.01 & 2.72 & 5.3 & 3.57 & 4.02 & 0.5 & 3.91 & 3.66 \\
\hline $\mathrm{K}_{2} \mathrm{O}$ & 0.01 & 0.22 & 0.55 & 0.1 & 0.08 & 2.23 & $<0.01$ & 0.13 \\
\hline $\mathrm{TiO}_{2}$ & 0.001 & 2.242 & 2.481 & 2.041 & 4.899 & 0.439 & 5.83 & 1.674 \\
\hline $\mathrm{P}_{2} \mathrm{O}_{5}$ & 0.01 & 0.3 & 0.27 & 0.24 & 0.11 & 0.08 & 1.01 & 0.19 \\
\hline LOI & & 3.51 & 1.87 & 2.69 & 2.82 & 20.31 & 0.39 & 3.75 \\
\hline Total & & 100.8 & 99.94 & 98.41 & 99.48 & 98.78 & 101 & 98.78 \\
\hline
\end{tabular}

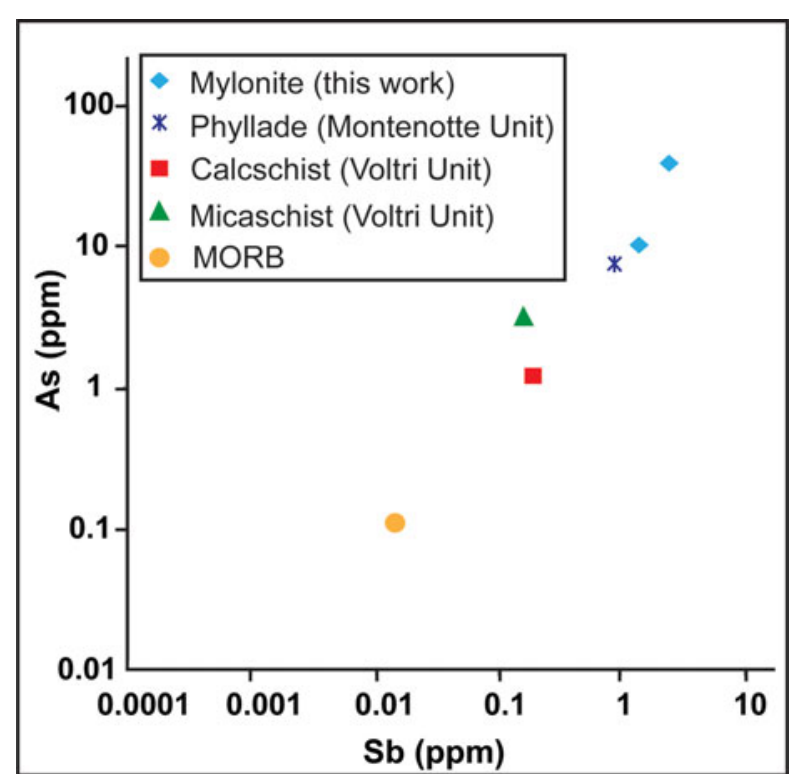

Figure 10. (Colour online) As vs Sb diagram comparing contents of the studied MM with those of metasediments from the Ligurian and Western Alps (explanation in the text). Voltri metasediment data are after Cannaò et al. (2016); the values of the Montenotte Unit metasediment are unpublished data.

relatively high depths and did not release them into fluids.

\section{5. $P-T$ pseudosection}

The $P-T$ stability conditions of mineral paragenesis along the main mylonitic foliation have been envisaged through $P-T$ pseudosections. We selected the bulk-rock composition of sample M1M2 since this was the most homogeneous sample in terms of grain size and the least affected by necks and veins. Pseudosections were calculated using Perple_X (Connolly, 1990; www.perplex.ethz.ch) and the internally consistent thermodynamic database of Holland \& Powell (1998) as revised by the authors in 2004 (hp04ver.dat).

We calculated the stable assemblages in the KCNMnTiFMASH system, considering $\mathrm{H}_{2} \mathrm{O}$ in excess $(\mathrm{aH} 2 \mathrm{O}=1$; Fig. 11) and using the equation of state for
$\mathrm{H}_{2} \mathrm{O}$ after Holland \& Powell (1998); $\mathrm{H}_{2} \mathrm{O}$ is considered in excess because of the occurrence of a high amount of stable hydrated minerals. The used bulk-rock composition matches the effective bulk-rock chemistry as we do not have any mineralogical relics (e.g. magmatic pyroxene or garnet) that could influence the effective bulk rock composition. We neglected $\mathrm{CO}_{2}$ because the occurrence of sphene instead of rutile implies a very low $\mathrm{CO}_{2}$ activity (e.g. Castelli et al. 2007).

If we consider total iron as $\mathrm{FeO}$, pseudosections do not exactly reproduce the mineralogical associations observed in the sample, especially with reference to epidote stability; we therefore added $\mathrm{Fe}_{2} \mathrm{O}_{3}$ to the system. In order to estimate the exact $\mathrm{Fe}^{3+}$ content in the rock, we produced pseudosections for several fixed $\mathrm{Fe}_{2} \mathrm{O}_{3}$ amounts (i.e. 10, 20, 40, 50, 60\% of $\mathrm{Fe}_{\text {tot }}$ ). The pseudosection that best reproduces the observed mineral assemblage includes $\mathrm{Fe}_{2} \mathrm{O}_{3}=20 \% \mathrm{Fe}_{\text {tot }}$ (Fig. 11).

We calculated the $\mathrm{Na}$ molar fraction in white mica as $\mathrm{X}_{\mathrm{Na}}=\mathrm{Na} /(\mathrm{Na}+\mathrm{K})$, and the Fe molar fraction in epidote as $X_{e p}=\mathrm{Fe} /(\mathrm{Fe}+\mathrm{Al})$. We used the following solid-solution models (solut_07.dat): GlTrTs and TrTsPg(HP) after White, Powell \& Phillips, (2003) and Wei \& Powell (2003) for amphibole; Chl(HP) after Holland, Baker \& Powell, (1998) for chlorite; Ep(HP) after Holland \& Powell (1998) for epidote; Gt(HP) after Holland \& Powell (1998) for garnet; Pheng(HP) after Holland \& Powell (1998) and KN-Phen after Chatterjee \& Froese (1975) for white mica; Cpx(HP) after Zeh et al. (2005) and Omph(HP) after Holland \& Powell (1996) for clinopyroxene.

The selected pseudosection contains di-, tri-, quadriand penta-variant fields depicted in light- to dark-grey colours. The assemblage observed in the rock is well described by the field including ep $+\mathrm{Na}$-amph $+\mathrm{w}$ mica + spn $+\mathrm{chl}+\mathrm{qtz}+$ hem at c. $T=220-310^{\circ} \mathrm{C}$ and $\mathrm{P}=2-6.5 \mathrm{kbar}$.

The isopleths of $X_{e p}$ in epidote suggest that the sample crossed a higher $P-T$ field (dashed circle in Fig. 12a) characterized by the appearance of a $\mathrm{Ca}-\mathrm{Na}$ clinopyroxene inside the stability field of $\mathrm{Mg}$-riebeckite. However, because of the presence of 


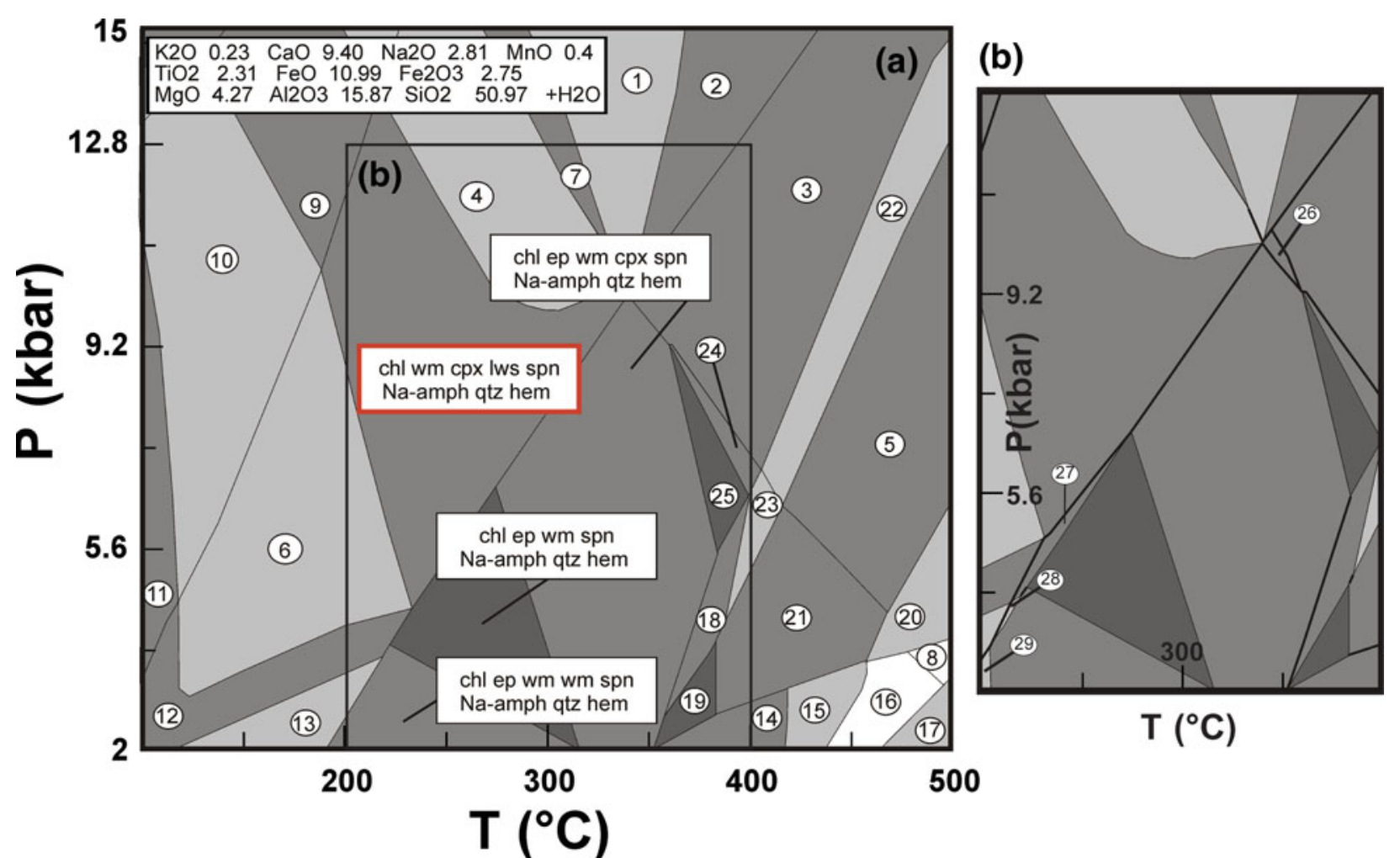

1. chl wm grt cpx Iws Na-amph qtz rt hem

2. chl wm grt cpx lws qtz rt hem

3. chl ep wm grt cpx qtz rt hem

4. chl wm cpx Iws spn Na-amph qtz rt hem

5. chl ep wm grt cpx qtz rt mag

6. chl wm cpx adr Iws spn Na-amph qtz hem

7. chl wm cpx lws Na-amph qtz rt hem

8. chl ep Na-amph wm grt cpx ab qtz rt mag

9. chl wm cpx Iws spn Na-amph qtz gt

10. chl wm cpx adr lws spn Na-amph qtz gt

11. chl wm adr lws spn Na-amph qtz gt

12. chl wm adr lws spn Na-amph qtz hem

13. chl wm wm adr lws spn Na-amph qtz hem

14. chl ep wm cpx spn ab qtz mag

15. chl ep wm grt cpx spn ab qtz mag

\author{
16. chl ep Na-amph wm grt cpx spn ab qtz mag \\ 17. ep Ca-amph Na-amph wm grt spn ab qtz rt mag \\ 18. chl ep wm cpx spn qtz hem mag \\ 19. chl ep wm cpx spn qtz mag \\ 20. chl ep Na-amph wm grt cpx qtz rt mag \\ 21. chl ep wm grt cpx spn qtz mag \\ 22. chl ep wm grt cpx qtz rt hem mag \\ 23. chl ep wm grt cpx spn qtz hem mag \\ 24. chl ep wm grt cpx spn qtz hem \\ 25. chl ep wm cpx spn qtz hem \\ 26. chl ep wm cpx Na-amph qtz rt hem \\ 27. chl ep wm Iws spn Na-amph qtz hem \\ 28. chl ep wm wm lws spn Na-amph qtz hem \\ 29. chl ep wm wm adr spn Na-amph qtz hem
}

Figure 11. (Colour online) (a) $P-T$ pseudosection using PERPLE_X (sample M1M2). The mineral abbreviations are after Kretz (1983) except for: cpx (clinopyroxene), Na-amph (Na-amphibole), Ca-amph (Ca-amphibole) and wm (white mica). The red box depicts the inferred metamorphic peak conditions. Narrow and small fields have been neglected for the sake of clarity. (b) Detail of the above $P-T$ pseudosection, also including narrow and small fields. Thick lines represent univariant reactions.

lawsonite pseudomorphoses along the foliation, we suggest that the metamorphic peak stage could be represented by the field including $\mathrm{Na}-\mathrm{amph}+\mathrm{w}-\mathrm{mica}+$ cpx + lws + spn + chl + qtz + hem; these peak conditions have been restricted using the $P-T$ peak conditions of M1M3 sample, calculated with pseudosection, pointing to $T=220-310^{\circ} \mathrm{C}$ and $P=6.5-10 \mathrm{kbar}$ (Fig. 13a). The isopleths of $\mathrm{Si}$ and $\mathrm{X}_{\mathrm{Na}}$ content in white mica cross-cut in a low $P-T$ field (solid circle in Figs 12 b,c, 13a) marking the retrogressive stage.

\section{Discussion}

In the following, we treat (i) the deformative processes that affected the analysed outcrop, (ii) the origin of fluids and fluid-rock interactions, suggesting the pos- sible correlations among fluids, brittle deformation and seismicity; (iii) finally we propose a geodynamic interpretation for the tectono-metamorphic evolution of the study area.

\section{6.a. Progressive deformation}

The occurrence of several superposed structures formed under the same metamorphic conditions suggests that the MM underwent a progressive polyphase deformation history (Fig. 4; Table 1c). The presence of peculiar microstructures such as $\sigma$ - and $\delta$-type porphyroclasts, and passive folds with a similar geometry $\left(D_{1}\right.$ and $D_{2}$ folds; Fig. 4) testifies that deformation in the study area was initially non-coaxial in a shear zone; it evolved in a bulk coaxial deformation (regime of 

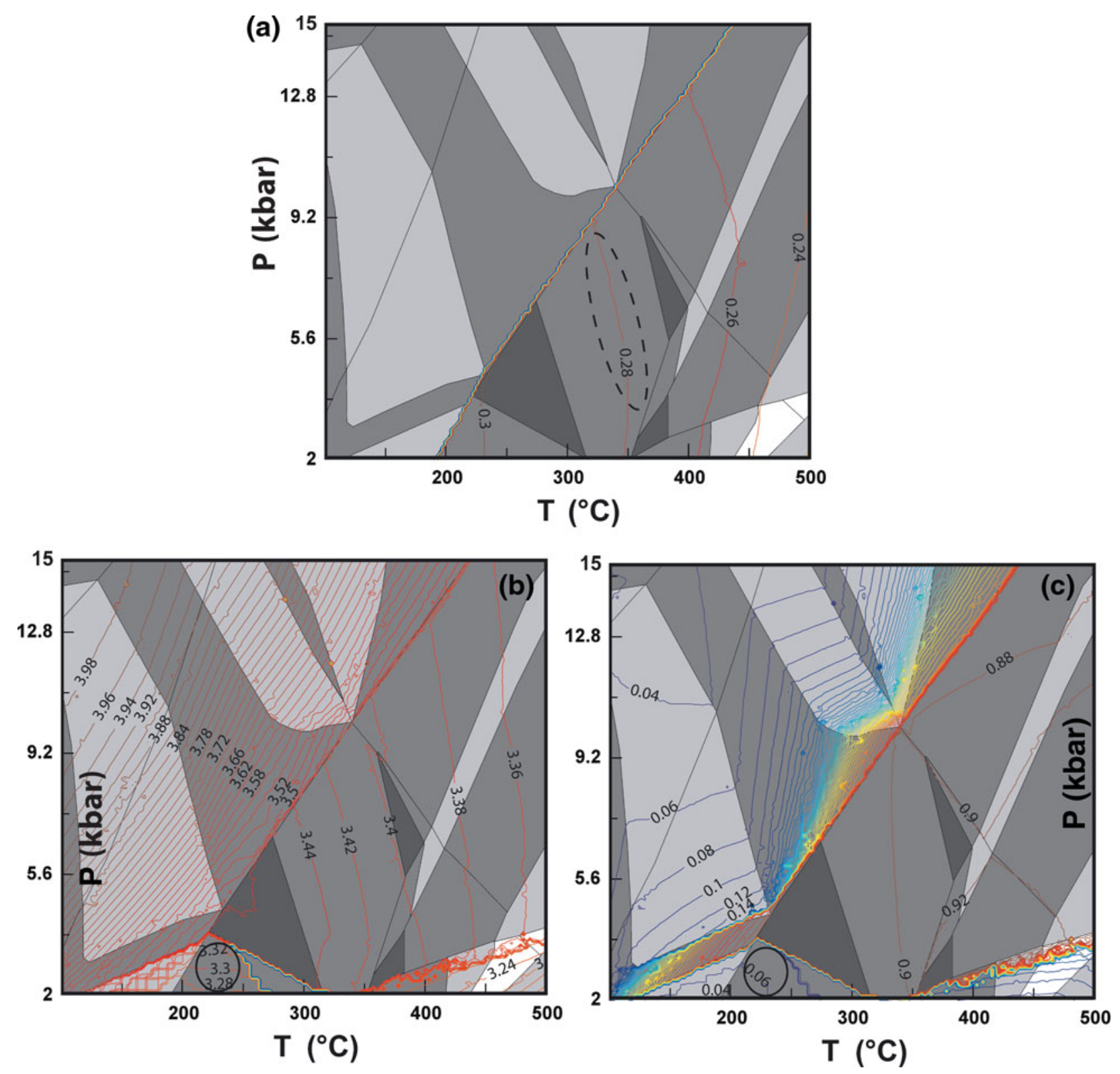

Figure 12. (Colour online) (a) Compositional isopleths for epidote ( $\mathrm{X}_{\mathrm{ep}}$ content); the dashed circle depicts the stability $P-T$ conditions of epidote in our sample. (b, c) Compositional isopleths for white mica ( $\mathrm{Si}$ and $\mathrm{X}_{\mathrm{Na}}$ content respectively); the circle shows the stability $P-T$ conditions of white mica in our sample.

general flattening) in the same structural level, producing a "chocolate-table" foliation boudinage. A minor component of shear is suggested by the presence of en échelon tension gashes and shear veins.

The next step in the deformative history is testified by brittle structures, such as veins and breccia. We exclude a primary origin for breccias because clasts contain an internal blueschist mylonitic foliation (Fig. 7b) that does not continue into the breccia cement and must therefore precede the brecciation event.

The transition from ductile deformation (folds; Fig. $5 b$ ) to brittle deformation (veining and breccias; Figs $5 \mathrm{~d}$, e, $7 \mathrm{~b}$ ) passing through a brittle-ductile regime (foliation boudinage) was therefore gradual; the occurrence of comparable mineral assemblages (Table 1c) along the foliation, in boudin necks, in the first three vein sets and in the breccia cement indicates that such ductile-brittle transition occurred within the same structural level, without a substantial change in the overall $P-T$ conditions (blueschist-facies metamorphic conditions). The direction of maximum extension derived from the boudins matches one derived by the veins and this corroborates the observation that these deformative events occurred within the same structural setting.

\section{6.b. The role and origin of fluids}

\section{6.b.1. The MM-fluids interaction}

Figure 10, Table 1 and Figure S4 (Supplementary Material) show that both fine-grained and ultra-finegrained $\mathrm{MM}$ have enriched $\mathrm{As}, \mathrm{Sb}$ (and $\mathrm{Pb}$ ) concentrations compared to MORB, and similar or, in the case of As, higher than arc magmas (Hattori \& Guillot, 2003). These elements, characterized by a high solubility in 
(a)

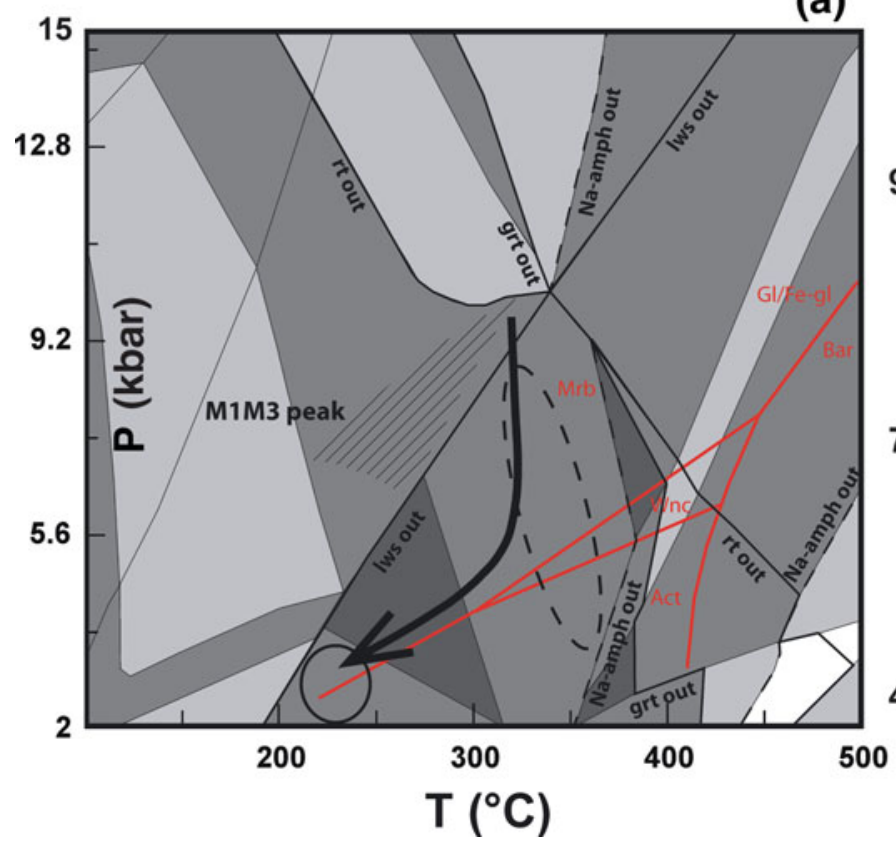

(b)

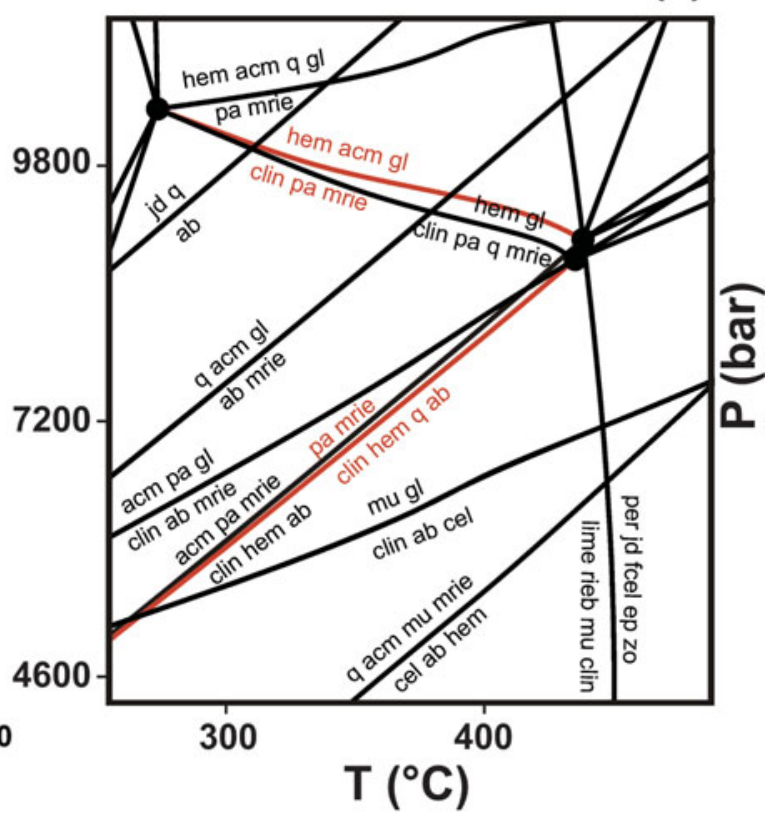

Figure 13. (Colour online) (a) Inferred $P-T$ path for M1M2 sample; the red lines delimit $P-T$ stability fields of amphibole (redrawn after Otsuki \& Banno, 1990; Mrb = Mg-riebeckite, Gl/Fe-gl = glaucophane/Fe-glaucophane, Wnc = winckite, Act = actinolite, Bar = barroisite); the solid and dashed circles show the stability $P-T$ conditions of white mica and epidote, respectively. (b) Schreinemakers diagram (KNCFMASH(O) system), drawn using Perple_X and the thermodynamic database after Holland \& Powell (1998, revised 2004; hp04ver.dat). We considered $\mathrm{H}_{2} \mathrm{O}$ in excess $(\mathrm{aH} 2 \mathrm{O}=1)$ and we used the equation of state for $\mathrm{H}_{2} \mathrm{O}$ after Holland \& Powell (1998). Red lines are the selected reactions.

aqueous fluids at low temperature, can reach high contents in the subducting slab (i.e. metasediments and serpentinite) and are generally released after its dehydration in the forearc mantle wedge during the early stage of subduction and incorporated inside the magmas also enriching volcanic fronts (Hattori \& Guillot, 2003; Sadofsky \& Bebout, 2003; John et al. 2004; Bebout, 2007).

In our rocks, the enrichment in fluid mobile elements, and in particular in $\mathrm{As}, \mathrm{Sb}$ and $\mathrm{Pb}$, could have several origins. The three main hypotheses are:

(1) enrichment of the protolith: the present composition could simply reflect the composition of the protolith, already enriched in $\mathrm{As}, \mathrm{Sb}$ and $\mathrm{Pb}$ compared to a MORB;

(2) ocean-floor alteration: the present composition could reflect the composition of the protolith that has been enriched by $\mathrm{As}-\mathrm{Sb}-\mathrm{Pb}$-rich fluids during ocean-floor alteration; our rocks could thus preserve the oceanic fingerprint and have carried fluid mobile elements in subduction at high depths without releasing them;

(3) interaction with fluids during subduction: our rocks could have interacted with external fluids, possibly released by other lithologies during subduction with increasing temperature (i.e. Voltri metasediments; Tpeak $=400-500{ }^{\circ} \mathrm{C}$; Cimmino $\&$ Messiga, 1979). The fluids were possibly rich in fluid mobile elements (e.g. As and Sb), now stored in amphibole, apatite or Fe-oxide (Smedley \& Kinniburgh, 2002).
The first two hypotheses would imply a local-scale fluid circulation restricted to a sort of close chemical system; the third hypothesis would imply an external input of fluids and a large fluid flux.

However, neither the enrichment of the protolith nor the ocean-floor alteration seems to be the case, because both metabasite and metagabbro of the Montenotte Unit, representing the possible undeformed equivalent of the MM, show a very low content of fluid mobile elements (e.g. As, Sb; Fig. 10), suggesting that these elements come from an external source. Moreover $\mathrm{P}_{2} \mathrm{O}_{5}$ and total iron content in our MM, and in meta-Fegabbro, metabasalt of the Montenotte Unit, are comparable, which implies that the high content of fluid mobile elements in the MM is not only related to a higher content of apatite or Fe-oxide. As, Sb and $\mathrm{Pb}$ are chalcophile elements, suggesting that sulphides may have some role in their enrichment (Hattori \& Guillot, 2003). All our samples, however, contain a very low amount of sulphides (local tiny inclusions in Fe-oxide), and other chalcophile elements such as $\mathrm{Cu}$ are not enriched. In addition, $\mathrm{Sr}$ and $\mathrm{Ce}$, elements unrelated to sulphides, are also enriched. Therefore, $\mathrm{S}$ cannot be considered responsible for the observed enrichment.

Figure 10 shows a distinction between the 'lowgrade' metasediments of the Montenotte Unit (phyllade) and those of the Voltri Unit, the latter recording higher metamorphic conditions (Cimmino \& Messiga, 1979) and containing a lower amount of As and Sb. Bebout et al. (2007) observed that the rocks that experienced high-temperature paths $\left(>350^{\circ} \mathrm{C}\right)$ record a 
dramatic depletion of fluid-mobile elements such as $\mathrm{Cs}, \mathrm{B}, \mathrm{As}, \mathrm{Sb}$ and $\mathrm{N}$, whereas rocks experiencing the cooler paths largely retain these elements (i.e. lawsonite-albite and lawsonite-blueschist rocks).

The content in $\mathrm{As}$ and $\mathrm{Sb}$ of our enriched $\mathrm{MM}$ falls into the field of low-grade metasediments close to the composition of phyllade, suggesting that the MM may have interacted with external fluids coming from a lithology that suffered dehydration; this lithology may have been the Voltri high-pressure metasediment, which during subduction, with increasing $T$, progressively discharged fluids rich in incompatible elements, i.e. As and $\mathrm{Sb}$ (Hattori \& Guillot, 2003). In the literature, serpentinite has been considered as another possible source of hydrous fluid, together with sediments, which infiltrate the slab-mantle interface (Nelson, 1991; Rupke et al. 2004; Tenthorey \& Hermann, 2004; Ranero et al. 2005; Hattori \& Guillot, 2007; Spandler et al. 2008; Spandler, Pettke \& Rubatto, 2011; Angiboust et al. 2014). Serpentinite is thought to release hydrous fluids rich in $\mathrm{B}, \mathrm{As}, \mathrm{Sb}, \mathrm{Nb}, \mathrm{Zr}$ and light rare earth elements (LREE) (Scambelluri et al. 2004; Hattori \& Guillot, 2007; Spandler, Pettke \& Hermann, 2009), and the interaction with serpentinite or serpentinite-derived fluids is responsible for the enrichment in $\mathrm{Cr}, \mathrm{Ni}$ and $\mathrm{Mg}$ (Angiboust et al. 2014). Although serpentinite is abundant in the study area and even if we lack in-depth geochemical studies (i.e. $\mathrm{B}$ isotopes), in a first approximation we exclude this rock as a possible source of fluids: $\mathrm{Cr}$, $\mathrm{Ni}$ and $\mathrm{Mg}$ content in the mylonite is in fact comparable to or even lower than (in the case of $\mathrm{Mg}$ ) ocean-floor gabbro or MORB (Table 1; Fig. S5 in Supplementary Material). Moreover, sediments are generally the first lithology to release fluids even at shallow depths (both pore and crystal lattice water); with increasing temperature, they release fluids more easily with respect to serpentinite that release water at only $650-700^{\circ} \mathrm{C}$ at $2-4 \mathrm{GPa}$ (antigorite; Ulmer \& Trommsdorff, 1999), which are $P-T$ conditions in any case not reached by our MM; moreover, we did not observe clear signs of dehydration in serpentinite. Furthermore, sediment-derived fluids could also contribute to a second stage of serpentinization during the early stages of subduction at $200-400^{\circ} \mathrm{C}$ (Deschamps et al. 2011) or could produce significant enrichment of the serpentinite in As, Sb, B and $\mathrm{Pb}$ in early subduction stages (Lafay et al. 2013; Cannaò et al. 2015; Scambelluri, Pettke \& Cannaò, 2015).

\section{6.b.2. Fluids and brittle deformation}

As a consequence of ongoing deformation and of primary heterogeneities, the MM is composed of layers of different mineralogies and grain sizes and possibly containing different amounts of free fluids. In particular, the occurrence of ultra-fine-grained layers in the MM may have played a dual role in enhancing fracturing.
(1) Grain size has been demonstrated to be one of the main factors controlling uniaxial compressive strength in low-porosity rocks (Prikryl, 2001; Villeneuve, Diederichs \& Kaiser, 2012): strength increases with decreasing grain size, following a logarithmic law. Moreover, for low-porosity rocks, the stress difference at crack initiation grows with decreasing grain size (Hatzor \& Palchik, 1997). Therefore, the ultrafine-grained domains of the MM may have acted as stress risers (Sibson, 1980), focusing brittle deformation and promoting the formation of breccia horizons.

(2) Deformation-induced grain-size reduction, which possibly acted in the MM, can also decrease the permeability (Caine, Evans \& Foster, 1996) by sealing off the pore spaces (Philippot $\&$ Selverstone, 1991). This results in an increase in pore fluid-pressure, which could facilitate the opening of microcracks on a grain scale by reducing the fracture strength of the grain aggregate (Philippot \& van Roermund, 1992).

The subsequent cracking, in turn, generates a fluidpressure drop that causes disequilibrium conditions at the vein walls, and the activation of mineralogical reactions; solution transfer to the vein finally induces mineral precipitation and growth. This is in agreement with the lower LOI content of ultra-fine-grained relative to fine-grained domains. As a consequence, we suggest that differences in grain size and in fluid content between adjacent domains may generate local strain and pore fluid-pressure partitioning; such rheological and fluid-pressure imbalance could have initiated microcrack on a $\mu \mathrm{m}$ to mm scale. Fracturing may therefore be interpreted in terms of brittle instabilities arising from strain and pore-fluid pressure partitioning between adjacent domains of the MM.

In our case, the local fluid-pressure drop triggered reactions that caused the disappearance in the vein wall of Na-amphibole (and phengite), and an increase of the mode of albite and paragonite. Schreinemakers diagrams, produced for the system KNCFMASH using Perple_X (Fig. 13b), suggest that paragonite and albite may have formed after the following decompression reactions:

(1) Fe-oxide + Na-pyroxene + Na-amphibole (glaucophane $)=$ chlorite + paragonite $+\mathrm{Na}-$ amphibole (Mg-riebeckite)

(2) paragonite + Na-amphibole $(\mathrm{Mg}$-riebeckite $)=$ chlorite + albite $+\mathrm{Fe}$-oxide + quartz

Reaction (1) implies the occurrence of Na-pyroxene, not observed in the present mineralogical assemblage, but occurring in the $P-T$ pseudosection simulated for the composition of our rock (Section 5 above). A Napyroxene could have been replaced by Na-amphibole during the development of the present blueschist foliation, with deformation possibly enhancing the disappearance of any textural or mineralogical relics. $\mathrm{Na}$ and $\mathrm{Mg}$ may not have been completely incorporated in the 
solid, and may have remained dissolved in the intercrystalline fluid, phase, retaining a sort of 'ghost Napyroxene' signature; when the fractures formed and the fluid pressure locally dropped, the solution was thus attracted towards the vein, enriching the vein wall in $\mathrm{Na}$ and $\mathrm{Mg}$ and allowing reaction (1). After the breakdown of phengite and the partial substitution of epidote by albite, the fluid migrating in the vein incorporated $\mathrm{K}$ and $\mathrm{Ca}$.

Concerning veins and breccia formation, the fact that the veins and the MM contain identical mineralogy confirms that the scale of fluid and isotopic equilibration was very small, thus arguing for short-range mass-transfer processes ( $\mathrm{cm}$-scale fluid-phase diffusional mass transport) and a locally derived fluid rather than fluid infiltration over a relatively large scale, leading to fluid and stable isotope equilibration (Philippot \& van Roermund, 1992; Spandler, Pettke \& Rubatto, 2011).

Veins thus have a rather contemporaneous growth history, and the scarcity of dehydration reactions in the wall rock suggests that dehydration embrittlement is not a likely mechanism for vein and breccia formation. Confirming this statement, the breccia is characterized by low dilation ratio (the volume ratio between void and clast), angular clasts and only incipient rotation of clasts, thus lacking the typical features of hydraulic breccia (Sibson, 1986; Jébrak, 1997) and suggesting a negligible fluid transport action.

The depth of fracture opening and brecciation can be inferred from the mineral assemblage in the vein infill and breccia matrix; the pressure range of $c$. 2-6.5 kbar, derived by the $P-T$ pseudosection fields, suggests that such conditions are in the range 7-20 km (Fig. 13a).

\section{6.b.3. Fluids, fracturing and seismicity}

As we have already seen, fracturing may be interpreted in terms of brittle instabilities arising from strain and pore-fluid pressure partitioning. In this way of thinking, the fracture mesh affecting the MM may represent the field evidence of episodic tremors or 'slow earthquakes' caused by overpressured fluids at the plate interface (Obara, 2002; Kato 2010; Katayama et al. 2012). It has been proposed that high pore pressure provided by hydrous fluids might facilitate faulting by decreasing the friction and thus triggering intermediate-depth seismicity (Davies, 1999 and references therein; Katayama et al. 2012).

Sibson (1996) estimated that, to generate a fracture mesh similar to the one described in this paper (disregarding the secondary non-coaxial component) in a compressional setting, we need lithostatic fluid pressure with:

$\lambda_{\mathrm{v}} \approx 1$ (the pore-fluid factor: $\lambda_{\mathrm{v}}=P_{\mathrm{f}} / \sigma_{\mathrm{v}}=P_{\mathrm{f}} / \rho g z ; P_{\mathrm{f}}=$ fluid pressure, $\sigma_{\mathrm{v}}=$ vertical stress, $\rho=$ average rock density, $g=$ gravitational acceleration, $z=$ depth) at all depths.

This high pore pressure will reduce the effective normal stresses and promote earthquakes. Several au- thors have demonstrated that fracture under pressure at low depth results from the coalescence of dilating tensile microcracks (Davies, 1999 and references therein); they propose that isolated pockets of water would nucleate microcracks and water would flow locally to hold them open. With increasing strain, these microcracks would interact to give echelon crack arrays (as we locally observe in our rock), extend and coalesce (Du \& Aydin, 1991). This would nucleate rupture, which would then propagate through the waterfilled microcracks, leading to substantial slip, stress drop and an earthquake (Davies, 1999). The earthquake, connecting water-filled microcracks, would increase porosity and permeability in the rock (Davies, 1999 and references therein). The set of veins affecting our MM, locally focused in the breccia horizons, could therefore be a record of multiple microcracks occurring during increasing strain and thus possibly originating low-frequency tremors or slow-slip seismic events. This is in agreement with observations and models of slow slip and tremor that require the presence of near-lithostatic pore-fluid pressures in slow-earthquake source regions (Audet \& Bürgmann, 2014).

A field setting similar to the one described in this paper, i.e. with relatively strong metabasitic horizons - deforming in a discontinuous manner - enveloped by lower-strength rocks (serpentinites and metasediments) where deformation is accommodated viscously, has been considered a viable source of tremor and slow slip events (Fagereng, Hillary \& Diener, 2014; Hayman \& Lavier, 2014).

Finally, the occurrence of various vein sets and/or of multiple opening stages in a single set (e.g. set number 3; see Section. 4.2) suggests that these brittle structures likely formed during different successive slow events.

\section{6.b.4. Fluid pressure and geological setting}

To achieve veining and brecciation inside the MM, fluids need to have been confined within the mylonitic horizon by the occurrence of a 'cap rock' above, possibly serpentinite.

The permeability of the intact MM is difficult to estimate, but is probably very low, in the order of magnitude of that for diabase (De Wiest, 1965), i.e. $10^{-9}$ darcy $\left(\right.$ c. $\left.10^{-23} \mathrm{~m}^{2}\right)$. However, fractured basaltic rocks have shown in situ permeabilities as high as $10^{-2}-10^{2}$ darcy (c. $10^{-16}-10^{-12} \mathrm{~m}^{2}$; Brace, 1980). In general, it is believed that in situ permeability of crystalline rocks is $10^{3}$ greater than laboratory measurements, which represent a measure of the minimum permeability (Brace, 1980). Permeability in serpentinite, in the absence of dehydration due to antigorite breakdown, is estimated at $c .10^{-22} \mathrm{~m}^{2}$ (Tenthorey \& Cox, 2003); in particular, permeability has been shown to vary between $10^{-22} \mathrm{~m}^{2}$ perpendicular to foliation and $10^{-20} \mathrm{~m}^{2}$ parallel to foliation (Kawano et al. 2011). In any case, it is able to act as 'cap rock', and therefore 


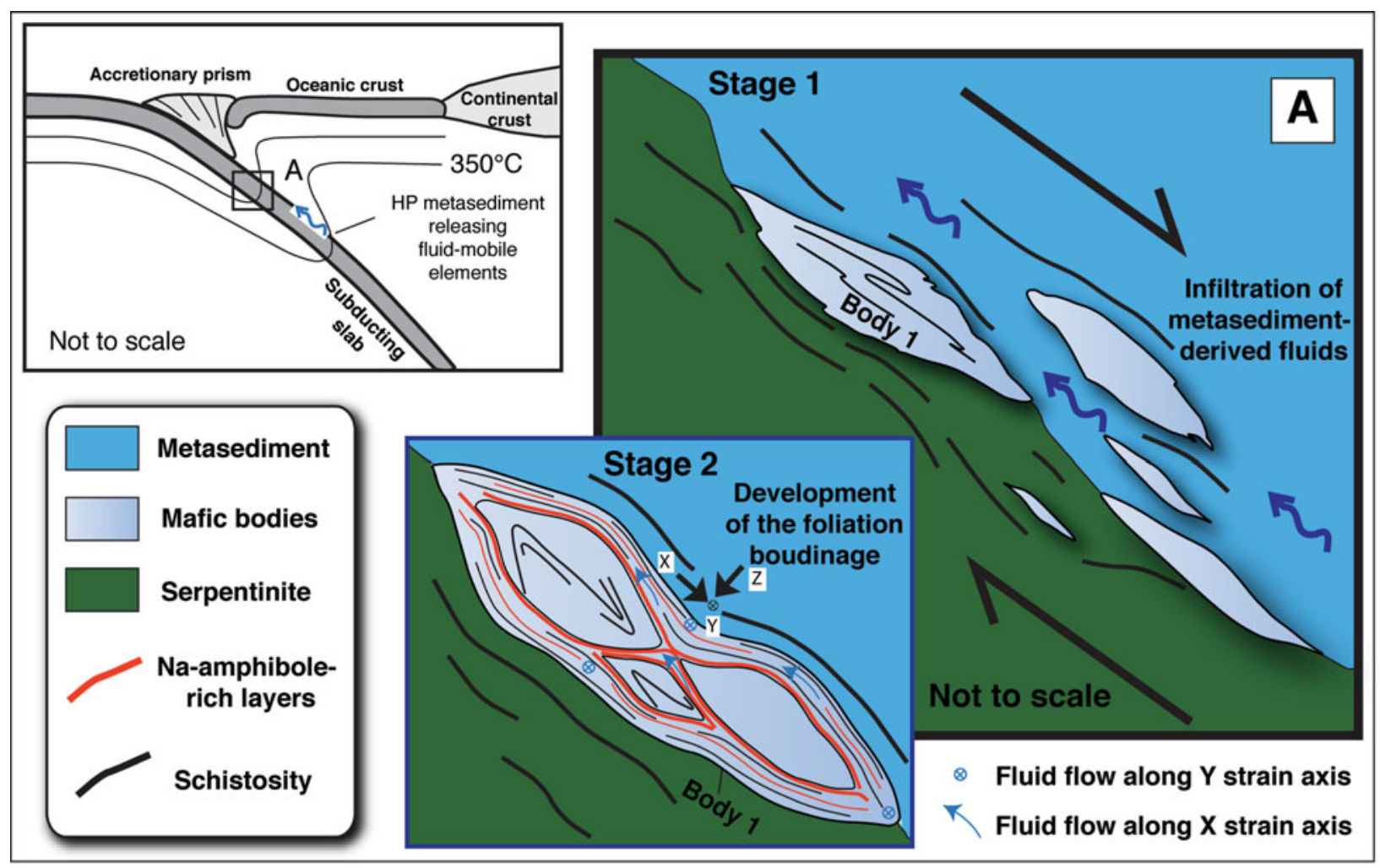

Figure 14. (Colour online) Sketch of the geodynamic evolution of the studied MM. Fluids are shown to flow either along X or Y strain axes. Box A shows a detail of the plate interface.

serpentinite may have acted as a barrier to fluid flow, facilitating the attainment of fluid overpressure inside the MM.

The local dilatancy, associated with fracture opening, will give rise to local pressure gradients between the fractured domains and the immediately surrounding rock (Etheridge et al. 1984). These pressure gradients would cause a fluid flow inside the MM, which could potentially be along both $\mathrm{X}$ and $\mathrm{Y}$ strain axes, in a situation of almost radial extension (Fig. 14).

\section{6.c. Geodynamic implications}

The MM horizon that we studied is sandwiched between metasedimentary rocks of the Voltri Unit and serpentinite of the Montenotte Unit, lying respectively at the bottom and at the top of the MM. The observed blueschist mineralogical assemblage (peak conditions at $c . T=220-310^{\circ} \mathrm{C}$ and $P=6.5-10 \mathrm{kbar}$ ) testifies that this rock has been buried during subduction down to crustal depths (c. $33 \mathrm{~km})$ (Fig. 13a).

Both chemical and petrographical evidence suggests that during subduction (at least during the development of the former foliation) the MM interacted with external aqueous fluids and behaved like a sponge incorporating them. Fluids were probably released by high-pressure metasediments (i.e. Voltri metasediments) at increasing temperature $\left(>350^{\circ} \mathrm{C}\right)$, during progressive subduction, and percolated upwards along a strongly deforming shear zone probably correspond- ing to the subducting plate interface or close to it (Fig. 14). This highly deformed mylonitic horizon incorporated the fluids, triggering the development of the hydrous blueschist-facies paragenesis. Previous studies (John et al. 2004; Bebout, 2007 and references therein) have shown that intensively deformed zones represent domains of structural weakness, where fluid flux and metasomatism is concentrated, with element gains and losses. Breeding et al. (2003) demonstrated that lithologic contacts are important conduits for metamorphic fluid flow in subduction zones. KonradSchmolke, O'Brien \& Zack, (2011), summarizing a series of natural examples, highlighted that in the slabmantle transition zone, fluid flux is controlled by the extent of viscous deformation, is channelized in ductile shear zones and is mostly parallel to the slab-mantle interface; here the involved bodies experience a pervasive fluid flow along grain boundaries and a strong fluid-rock interaction.

This evidence suggests that the MM, now outcropping at the border between units in different metamorphic peak conditions, was part of a highly deformed zone, i.e. the plate interface, where an important flux of fluids was active.

\section{Concluding remarks}

The blueschist-facies MM outcropping between the blueschist-facies Montenotte Unit and the eclogitefacies Voltri Unit (Ligurian Western Alps) is an 
example of rock permeated by fluids under highpressure conditions. This MM probably acted as a shear zone at the contact between units characterized by different metamorphism, probably close to the plate interface in the subduction zone, where chemically reacting fluids preferentially flowed, allowing the enrichment of the MM by incompatible elements (i.e. As, Sb), released by high-grade metasediments. The deformation-induced fracturing, occurring under metamorphic conditions similar to those of the mylonitic foliation development $\left(T=220-310^{\circ} \mathrm{C}\right.$ and $P=2$ $6.5 \mathrm{kbar}$ ), attests that fluids were present at highpressure blueschist metamorphic conditions. Fracturing here was related to the cycling between ductile deformation, pore-fluid pressure increase and brittle deformation, testifying to a short-range mass-transfer process. Fluids migrated through the body, taking advantage of surfaces along boudins and veins; locally, fracturing was pervasive, producing breccia horizons and a dense mesh of interconnected channels for fluid flow. We finally propose that the fracture mesh affecting the MM is likely a record of past episodic tremors or 'slow earthquakes', caused by overpressured fluids.

Acknowledgements. We acknowledge Silvia Torchio for field assistance. This work benefited from the financial support of the PRIN 2010 project 'Nascita e morte dei bacini oceanici: processi geodinamici dal rifting alla collisione continentale negli Orogeni mediterranei e circummediterranei”, national coordinator G. Capponi.

\section{Supplementary material}

To view supplementary material for this article, please visit http://doi.org/10.1017/S0016756816001163

\section{References}

Able, L. \& Brady, J. B. 2001. Lawsonite pseudomorphs in the schists of Syros, Greece. Geological Society of America, Abstracts with Programs 33, A9.

Anders, E. \& EbiharA, M. 1982. Solar system abundances of the elements. Geochimica et Cosmochimica Acta 46, 2363-80.

Anfossi, R., Colella, S. \& Messiga, B. 1984. Posizione strutturale e assetto litologico interno della falda di Montenotte, nella zona compresa tra i torrenti Letimbro e Sansobbia. Memorie della Societa Geologica Italiana 28, 371-84.

Angiboust, S. \& AGARD, P. 2010. Initial water budget: the key to detaching large volumes of eclogitized oceanic crust along the subduction channel? Lithos 120, 45374.

Angiboust, S., Pettke, T., De Hoog, J. C. M., Caron, B. \& ONCKEN, O. 2014. Channelized fluid flow and eclogitefacies metasomatism along the subduction shear zone. Journal of Petrology 55(5), 883-916.

Arslan, A., Passchier, C. W. \& Koehn, D. 2008. Foliation boudinage. Journal of Structural Geology 30, 291-309.

Audet, P., Bostock, M. G., Boyarko, D. C., Brudzinski, M. R. \& Allen, R. M. 2010. Slab morphology in the Cascadia fore arc and its relation to episodic tremor and slip. Journal of Geophysical Research 115, B00A16. doi: 10.1029/2008JB006053.

Audet, P. \& Bürgmann, R. 2014. Possible control of subduction zone slow-earthquake periodicity by silica enrichment. Nature 510, 389-92.

Bebout, G. E. 2007. Metamorphic chemical geodynamics of subduction zones. Earth and Planetary Science Letters 260, 373-93.

Bebout, G. E. \& Barton, M. D. 1989. Fluid flow and metasomatism in a subduction zone hydrothermal system: Catalina schist terrane, California. Geology 17, 976-80.

Bebout, G. E. \& Penninston-Dorland, S. C. 2016. Fluid and mass transfer at subduction interfaces - the field metamorphic record. Lithos 240-243, 228-58.

Beccaluva, L., Macciotta, G., Messiga, B. \& Piccardo, G. B. 1979. Petrology of the Blue-Schists metamorphic ophiolites of the Montenotte Nappe (Western Liguria Italy). Ofioliti 4, 239-68.

Bocchio, R. 1995. Chemical variations in clinopyroxenes and garnet from eclogites of the Vara Valley (Voltri Group), Italy. European Journal of Mineralogy 7(10), 103-17.

BRACE, W. F., 1980. Permeability of crystalline and argillaceous rocks. International Journal of Rock Mechanics and Mining Sciences \& Geomechanics Abstracts 17(5), 241-51.

Breeding, C. M., Ague, J. J. \& Bröcker, M. 2004. Fluidmetasedimentary rock interactions in subduction-zone mélange: implications for the chemical composition of arc magmas. Geology 32, 1041-4.

Breeding, C. M., Ague, J. J., Bröcker, M. \& Bolton, E. W. 2003. Blueschist preservation in a retrograded, high-pressure, low-temperature metamorphic terrane, Tinos, Greece: implications for fluid flow paths in subduction zones. Geochemistry, Geophysics, Geosystems 4(1), 9002. doi: 10.1029/2002GC0000380.

Brouwer, F. M., Vissers, R. L. M., \& LAMB, W. M. 2002. Metamorphic history of eclogitic metagabbro blocks from a tectonic melange in the Voltri Massif, Ligurian Alps, Italy. Ofioliti 27(1), 1-16.

Cabella, R., Cortesogno, L., Gaggero, L. \& Lucchetti, G. 1994. Clinopyroxenes through the blueschist facies metamorphism of the Liguria Alps: compositional variability and miscibility gaps. Atti Ticinensi di Scienze della Terra, Serie Speciale 1, 55-63.

Caine, J. S., Evans, J. P. \& Foster, C. B. 1996. Fault zone architecture and permeability structure. Geology 24, $1025-8$.

Cannaò, E., Agostini, S., Scambelluri, M., Tonarini, S. \& GoDARD, M. 2015. B, Sr and Pb isotope geochemistry of high-pressure Alpine metaperidotites monitors fluid-mediated element recycling during serpentinite dehydration in subduction mélange (Cima di Gagnone, Swiss Alps). Geochimica et Cosmochimica Acta 163, 80-100.

Cannaò, E., Scambelluri, M., Agostini, A., Tonarini, S. \& GODARD, M. 2016. Linking serpentinite geochemistry with tectonic evolution at the subduction interface: the Voltri Massif case study (Ligurian Western Alps, Italy). Geochimica et Cosmochimica Acta 190, 115-33.

CAPPONI, G. \& CRispini, L. 2002. Structural and metamorphic signature of alpine tectonics in the Voltri Massif (Ligurian Alps, northwestern Italy). Eclogae Geologicae Helvetiae 95, 31-42.

CAPPONI, G. \& CRispini, L. 2008. Note illustrative del Foglio 213-230 'Genova' della Carta Geologica d'Italia alla scala 1:50.000. Apat - Regione Liguria, Italy. 
Capponi, G., Crispini, L. \& Federico, L. (with contributions by Cabella, R., Faccini, F., Ferraris, F., Firpo, M., Roccati, A., Marescotti, P., Piazza, M. \& ScAmbelluri, M. and collaboration by Dabove, G. M., Poggi, E., Torchio, S., Vigo, A. \& Vetuschi ZucColini, M.) 2013. Note illustrative al Foglio 212 'Spigno Monferrato' della Carta Geologica Regionale della Liguria. Retrieved from http://www.cartografia. regione.liguria.it/.

Capponi, G., Crispini, L., Federico, L. \& Malatesta, C. 2015. Geology of the Eastern Ligurian Alps: a review of the tectonic units. Italian Journal of Geosciences 135(1), 157-69.

Castelli, D., Rolfo, F., Groppo, C. \& Compagnoni, R. 2007. Impure marbles from the UHP Brossasco-Isasca Unit (Dora-Maira Massif, western Alps): evidence for Alpine equilibration in the diamond stability field and evaluation of the $\mathrm{X}(\mathrm{CO} 2)$ fluid evolution. Journal of Metamorphic Geology 25, 587-603.

Chatterjee, N. D. \& Froese, E. 1975. A thermodynamic study of the pseudo-binary join muscovite-paragonite in the system KAlSi3O8-NaAlSi3O8-Al2O3-SiO2H2O. American Mineralogist 60, 985-93.

Chiesa, S., Cortesogno, L., Forcella, F., Galli, M., Messiga, B., Pasquaré, G. \& Rossi, P. M. 1975. Assetto strutturale ed interpretazione geodinamica del Gruppo di Voltri. Bollettino della Società Geologica Italiana 94(3), 555-82.

Cimmino, F. \& Messiga, B. 1979. I calcescisti del Gruppo di Voltri (Liguria occidentale): le variazioni composizionali delle miche bianche in rapporto alla evoluzione tettono-metamorfica alpina. Ofioliti 4(3), 269-94.

Connolly, J. 1990. Multivariable phase diagrams: an algorithm based on generalized thermodynamics. American Journal of Sciences 290, 666-718.

Cortesogno, L., Gaggero, L., Lucchetti, G. \& Cabella, R. 2002. Compositional variability and miscibility gap in Na-Ca clinopyroxenes through high pressure metamorphism. Periodico di Mineralogia 71(1), 1-25.

Crispini, L. \& Frezzotti, M. L. 1998. Fluid inclusion evidence for progressive folding during decompression in metasediments of the Voltri Group (Western Alps, Italy). Journal of Structural Geology 20(12), 1733-46.

Davies, J. H., 1999. The role of hydraulic fractures and intermediate-depth earthquakes in generating subduction-zone magmatism. Nature 398, 142-5.

Deschamps, F., Guillot, S., Godard, M., Andreani, M. \& HATTORI, K. 2011. Serpentinites act as sponges for fluid-mobile elements in abyssal and subduction zone environments. Terra Nova 23, 171-8.

Desmons, J., Compagnoni, R. \& Cortesogno, L. 1999. Alpine metamorphism of the Western Alps: II. High $\mathrm{P} / \mathrm{T}$ and related pre-greenschist metamorphism. Schweizerische Mineralogische und Petrografische Mitteilungen 79, 111-34.

De WiEst, R. J. M. 1965. Geohydrology. New York: John Wiley, $366 \mathrm{pp}$.

Du, Y. \& AYDIN, A., 1991. Interaction of multiple cracks and formation of echelon crack arrays. International Journal for Numerical and Analytical Methods in Geomechanics 15(3), 205-18.

ERnst, W. G. 1976. Mineral chemistry of eclogites and related rocks from the Voltri Group, Western Liguria, Italy. Schweizerische Mineralogische und Petrografische Mitteilungen 56, 293-343.

Etheridge, M. A., Wall, V. J., Cox, S. F. \& Vernon, R. H., 1984. High fluid pressures during regional metamorphism and deformation: implications for mass transport and deformation mechanisms. Journal of Geophysical Research 89(B6), 4344-58.

Fagereng, Å., Hillary, G. W. B. \& Diener, J. F. A. 2014. Brittle-viscous deformation, slow slip, and tremor. Geophysical Research Letters 41, 4159-67.

FARYAD, S. W. \& HoInKes, G. 1999. Two contrasting mineral assemblages in the Meliata blueschists, Western Carpathians, Slovakia. Mineralogical Magazine 63(4), 489-501.

Federico, L., Capponi, G., Crispini, L. \& Scambelluri, M. 2004. Exhumation of alpine high pressure rocks: insights from petrology of eclogite clasts in the Tertiary Piedmontese basin (Ligurian Alps, Italy). Lithos 74(12), 21-40.

Federico, L., Capponi, G., Crispini, L., Scambelluri, M. \& Villa, I. M. 2005. ${ }^{39} \mathrm{Ar} /{ }^{40} \mathrm{Ar}$ dating of high-pressure rocks from the Ligurian Alps: evidence for a continuous subduction-exhumation cycle. Earth and Planetary Science Letters 240, 668-80.

Federico, L., Crispini, L., Malatesta, C., Torchio, S. \& CAPPONI, G. 2014. Geology of the Pontinvrea area (Ligurian Alps, Italy): structural setting of the contact between Montenotte and Voltri units. Journal of Maps 11(1), 1-13. doi: 10.1080/17445647.2014.945749.

Federico, L., Crispini, L., Scambelluri, M. \& CAPponi, G., 2007. Ophiolite mélange zone records exhumation in a fossil subduction channel. Geology 35(6), 499502.

Ford, M., Duchêne, S. \& GASQuet, D. 2006. Two-phase orogenic convergence in the external and internal SW Alps. Journal of the Geological Society 163, 81526.

GaO, J. \& Klemd, R. 2001. Primary fluids entrapped at blueschist to eclogite transition; evidence from the Tianshan meta-subduction complex in northwestern China. Contributions to Mineralogy and Petrology 142(1), 1-14.

Ghosh, S. K. \& Sengupta, S. 1987. Progressive development of structures in a ductile shear zone. Journal of Structural Geology 9(3), 277-87.

Hacker, B. R., Peacock, S. M., Abers, G. A. \& Holloway, S. D. 2003. Subduction factory 2. Are intermediatedepth earthquakes in subducting slabs linked to metamorphic dehydration reactions? Journal of Geophysical Research 108, 1-16.

Hattori, K. H. \& GuiLlot, S. 2003. Volcanic fronts form as a consequence of serpentinite dehydration in the forearc mantle wedge. Geology 31(6), 525-8.

Hattori, K. \& Guillot, S. 2007. Geochemical character of serpentinites associated with high- to ultrahighpressure rocks in the Alps, Cuba, and the Himalayas: recycling of elements in subduction zones. Geochemistry, Geophysics, Geosystems 8, Q09010. doi: 10.1029/2007GC001594.

Hatzor, Y. H. \& PalchiK, V. 1997. The influence of grain size and porosity on crack initiation stress and critical flaw length in dolomites. International Journal of Rock Mechanics and Mining Sciences 34(5), 805-16.

Hayman, N. W. \& LavieR, L. L. 2014. The geologic record of deep episodic tremor and slip. Geology 42(3), 195-8.

Holland, T., BaKer, J. \& Powell, R. 1998. Mixing properties and activity-composition relationships of chlorites in the system $\mathrm{MgO}-\mathrm{FeO}-\mathrm{Al}_{2} \mathrm{O}_{3}-\mathrm{SiO}_{2}-\mathrm{H}_{2} \mathrm{O}$. European Journal of Mineralogy 10, 395-406.

Holland, T. \& Powell, R. 1996. Thermodynamics of order-disorder in minerals. Symmetric formalism applied to solid solutions. American Mineralogist 81, 1425-37. 
Holland, T. \& Powell, R. 1998. An internally consistent thermodynamic data set for phases of petrological interest. Journal of Metamorphic Geology 16, 309-43.

JÉBRAK, M. 1997. Hydrothermal breccias in vein-type ore deposits: a review of mechanisms, morphology and size distribution. Ore Geology Reviews 12(3), 111-34.

John, T., Klemd, R., GAOD, J. \& GARBe-SchÖnberG, C. D. 2008. Trace-element mobilization in slabs due to non steady-state fluid-rock interaction: constraints from an eclogite-facies transport vein in blueschist (Tianshan, China). Lithos 103, 1-24.

John, T., Scherer, E., HaAse, K. M. \& Schenk, V. 2004. Trace element fractionation during fluid-induced eclogitization in a subducting slab: trace element and $\mathrm{Lu}-$ $\mathrm{Hf} / \mathrm{Sm}-\mathrm{Nd}$ isotope systematics. Earth and Planetary Science Letters 227, 441-56.

Katayama, I., Terada, T., OKazaki, K. \& Tanikawa, W. 2012. Episodic tremor and slow slip potentially linked to permeability contrasts at the Moho. Nature Geoscience 5(10), 731-4. doi: 10.1038/NGEO1559.

KAто, A. 2010. Variation of fluid pressure within the subducting oceanic crust and slow earthquakes. Geophysical Research Letters 37, L14310. doi: 10.1029/2010GL043723.

Kawano, S., Katayama, I. \& OKazaKi, K. 2011. Permeability anisotropy of serpentinite and fluid pathways in a subduction zone. Geology 39, 939-42.

Konrad-Schmolke, M., O’Brien, P. J. \& Zack, T. 2011. Fluid migration above a subducted slab: constraints on amount, pathways and major element mobility from partially overprinted eclogite-facies rocks (Sesia Zone, Western Alps). Journal of Petrology 52(3), 457-86.

KRETZ, R. 1983. Symbols for rock-forming minerals. American Mineralogist 68, 277-9.

Lafay, R., Deschamps, F., Schwartz, S., Guillot, S., Godard, M., Debret, B. \& Nicollet, C. 2013. Highpressure serpentinites, a trap-and-release system controlled by metamorphic conditions: example from the Piedmont zone of the Western Alps. Chemical Geology 343, 38-54.

Leake, B. E., Woolley, A. R., Arps, C. E. S., Birch, W. D., Gilbert, M. C., Grice, J. D., Hawthorne, F. C., Kato, A., Kisch, H. J., Krivovichev, V. G., Linthout, K., Laird, J., Mandarino, J. A., Maresch, W. V., Nickel, E. H., Rock, N. M. S., Schumacher, J. C., Smith, D. C., Stephenson, N. C. N., Ungaretti, L., Whittaker, E. J. W. \& Youzhi, G., 1997. Nomenclature of amphiboles: report of the subcommittee on amphiboles of the international mineralogical association, commission on new minerals and mineral names. The Canadian Mineralogist 35, 219-46.

Le Pichon, X., Henry, P. \& Lallemant, S. 1990. Water flow in the Barbados accretionary complex. Journal of Geophysical Research: Solid Earth 95, 8945-67.

Li, Y., Massonne, H. J., Willner, A., Tang, H. F. \& LiU, C. Q. 2008. Dehydration of clastic sediments in subduction zones: theoretical study using thermodynamic data of minerals. Island Arc 17, 577-90.

Liou, J. G., Zhang, R., Ernst, W. G., Liu, J. \& McLimans, R. 1998. Mineral parageneses in the Piampaludo eclogitic body, Gruppo di Voltri, Western Ligurian Alps. Schweiz. Mineralogische und Petrographische Mitteilungen 78, 317-35.

Malatesta, C., Crispini, L., Federico, L., Capponi, G. \& SCAMBELlURI, M. 2012a. The exhumation of high pres- sure ophiolites (Voltri Massif, Western Alps): insights from structural and petrologic data on meta-gabbro bodies. Tectonophysics 568/569, 102-23.

Malatesta, C., Gerya, T., Scambelluri, M., Crispini, L. \& CAPPONI, G., 2012b. Intraoceanic subduction of 'heterogeneous' oceanic lithosphere in narrow basins: 2D numerical modeling. Lithos 140-141, 234-51.

Messiga, B., Piccardo, G. B. \& Ernst, W. G. 1983. High pressure Eo-Alpine parageneses developed in magnesian metagabbros, Gruppo di Voltri, Western Liguria, Italy. Contributions to Mineralogy and Petrology 83, 115 .

Moore, J. C. \& VroliJK, P. 1992. Fluids in accretionary prisms. Reviews of Geophysics 30, 113-35.

Nelson, B. K. 1991. Sediment-derived fluids in subduction zones: isotopic evidence from veins in blueschist and eclogite of the Franciscan Complex, California. Geology 19(10), 1033-6.

OBARA, K. 2002. Nonvolcanic deep tremor associated with subduction in southwest Japan. Science 296(5573), 1679-81.

Otsuki, M. \& Banno, S. 1990. Prograde and retrograde metamorphism of hematite-bearing basic schists in the Sanbagawa belt in central Shikoku. Journal of Metamorphic Geology 8, 425-39.

PeAcock, S. M. 1993. The importance of blueschist to eclogite dehydration reactions in subducting oceanic crust. Geological Society of America Bulletin 105, 684-94.

Philippot, P. \& Selverstone, J. 1991. Trace-element-rich brines in eclogitic veins: implications for fluid composition and transport during subduction. Contributions to Mineralogy and Petrology 106, 417-30.

Philippot, P. \& VAN Roermund, H. L. M. 1992. Deformation processes in eclogitic rocks: evidence for the rheological delamination of the oceanic crust in deeper levels of subduction zones. Journal of Structural Geo$\log y$ 14(8-9), 1059-77.

PICCARDO, G. 1977. Le ofioliti dell'areale ligure: petrologia e ambiente geodinamico di formazione. Rendiconti Società Italiana di Mineralogia e Petrologia 33(1), 22152.

Polino, R., Dal Piaz, G. V. \& Gosso, G. 1990. Tectonic erosion at the Adria margin and accretionary processes for the Cretaceous orogeny of the Alps. Paris/Zürich/Rome: Société Géologique de France/Société Géologique Suisse/Società Geologica Italiana, pp. 345-67. Memoir no. 156 (new series)/no. $1 /$ special volume.

PRIKRYL, R. 2001. Some microstructural aspects of strength variation in rocks. International Journal of Rock Mechanics \& Mining Sciences 38, 671-82.

Rampone, E., Hofmann, A. W. \& Raczek, I. 1998. Isotopic contrasts within the Internal Liguride ophiolite $(\mathrm{N}$. Italy): the lack of a genetic mantle-crust link. Earth and Planetary Science Letters 163, 175-89.

Rampone, E., Romairone, A., Abouchami, W., Piccardo, G. B. \& Hofmann, A. W. 2005. Chronology, petrology and isotope geochemistry of the Erro-Tobbio peridotites (Ligurian Alps, Italy): records of Late $\mathrm{Pa}$ laeozoic lithospheric extension. Journal of Petrology 46(4), 799-827.

Ramsay, J. G. \& Huber, M. I. 1987. The Techniques of Modern Structural Geology, vol. 2: Folds and Fractures. London: Academic Press.

Ranero, C. R., Villasenor, A., Phipps Morgan, J. \& WeInREBe, W. 2005. Relationship between bendfaulting at trenches and intermediate-depth seismicity. 
Geochemistry, Geophysics, Geosystems 6, Q12002. doi: 10.1029/2005GC000997.

Rubatto, D. \& Hermann, J. 2003. Zircon formation during fluid circulation in eclogites (Monviso, Western Alps): implications for $\mathrm{Zr}$ and $\mathrm{Hf}$ budget in subduction zones. Geochimica et Cosmochimica Acta 67, 2173-87.

Rupke, L. H., Morgan, J. P., Hort, M. \& Connolly, J. A. D. 2004. Serpentine and the subduction zone water cycle. Earth and Planetary Science Letters 223, 17-34.

SAdofsky, S. J. \& Bebout, G. E. 2003. Record of forearc devolatilization in low- $\mathrm{T}$, high-P/T metasedimentary suites: significance for models of convergent margin chemical cycling. Geochemistry, Geophysics, Geosystems 4(4), 9003. doi: 10.1029/2002GC000412.

Scambelluri, M., Bebout, G. E., Belmonte, D., Gilio, M., Campomenosi, N., Collins, N. \& Crispini, L. 2016. Carbonation of subduction-zone serpentinite (highpressure ophicarbonate; Ligurian Western Alps) and implications for the deep carbon cycling. Earth and Planetary Science Letters 441, 155-66.

Scambelluri, M., Fiebig, J., Malaspina, N., Müntener, O. \& PetTKe, T. 2004. Serpentinite subduction: implications for fluid processes and trace element recycling. International Geology Review 46, 595-613.

Scambelluri, M., Pettke, T. \& Cannaò, E. 2015. Fluidrelated inclusions in Alpine high-pressure peridotite reveal trace element recycling during subduction-zone dehydration of serpentinized mantle (Cima di Gagnone, Swiss Alps). Earth and Planetary Science Letters 429, 45-59.

Scambelluri, M., Pettke, T., Rampone, E., Godard, M. \& Reusser, E. 2014. Petrology and trace element budgets of high-pressure peridotites indicate subduction dehydration of serpentinized mantle (Cima di Gagnone, Central Alps, Switzerland). Journal of Petrology 55, 459-98.

Scambelluri, M., Strating, E. H. H., Piccardo, G., VisSERS, R. L. M. \& RAMPONE, E. 1991. Alpine olivineand titanian clinohumite-bearing assemblages in the Erro-Tobbio peridotite (Voltri Massif, NW Italy). Journal of Metamorphic Geology 9, 79-91.

SCAMBelluRi, M. \& ToNARINI, S. 2012. Boron isotope evidence for shallow fluid transfer across subduction zones by serpentinized mantle. Geology 40(10), 907-10.

SchmidT, M. W. \& Poli, S. 1998. Experimentally based water budgets for dehydrating slabs and consequences for arc magma generation. Earth and Planetary Science Letters 163, 361-79.

Sibson, R. H. 1980. Transient discontinuities in ductile shear zones. Journal of Structural Geology 2, 1-2, 16571.

Sibson, R. H. 1986. Brecciation processes in fault zones: inferences from earthquake rupturing. Pageoph 124, 1-2.

Sibson, R. H. 1996. Structural permeability of fluid-driven fault-fracture meshes. Journal of Structural Geology 18(8), 1031-42.
Smedley, P. L. \& Kinniburgh, D. G. 2002. A review of the source, behaviour and distribution of arsenic in natural waters. Applied Geochemistry 17(5), 517-68.

Spandler, C., Hermann, J., Faure, K., Mavrogenes, J. \& Arculus, R. 2008. The importance of talc and chloritehybrid rocks for volatile recycling through subduction zones; evidence from the high-pressure subduction mélange of New Caledonia. Contributions to Mineralogy and Petrology 155, 181-98.

Spandler, C., Pettke, T. \& Hermann, J. 2009. The composition of serpentinite dehydration fluids in subduction zones: an experimental study. Geochimica et Cosmochimica Acta 73, Supplement 1, A1256.

Spandler, C., Pettke, T. \& Rubatto, D. 2011. Internal and external fluid sources for eclogite-facies veins in the Monviso meta-ophiolite, Western Alps: implications for fluid flow in subduction zones. Journal of Petrology 52(6), 1207-36.

Tenthorey, E. \& Cox, S.F., 2003. Reaction-enhanced permeability during serpentinite dehydration. Geology 31(10), 921-4.

Tenthorey, E. \& Hermann, J. 2004. Composition of fluids during serpentinite breakdown in subduction zones: evidence for limited boron mobility. Geology 32, 8658.

Ulmer, P. \& TrommsdorfF, V. 1999. Phase relations of hydrous mantle subducting to $300 \mathrm{~km}$. In Mantle Petrology: Field Observations and High-Pressure Experimentation (eds Y. Fei, C. M. Bertka \& B. Mysen), pp. 259-81. Special Publications of the Geochemical Society no. 6.

Vanossi, M., Cortesogno, L., Galbiati, B., Messiga, B., Piccardo, G. \& Vannucci, R. 1984. Geologia delle Alpi Liguri: dati, problemi, ipotesi. Memorie della Societa Geologica Italiana 28, 5-75.

Villeneuve, M., Diederichs, M. \& Kaiser, P. 2012. Effects of grain scale heterogeneity on rock strength and the chipping process. International Journal of Geomechanics 12, Special issue: Advances in Modeling Rock Engineering Problems, 632-47.

Wei, C. J. \& Powell, R. 2003. Phase relations in highpressure metapelites in the system KFMASH $\left(\mathrm{K}_{2} \mathrm{O}\right.$ $\mathrm{FeO}-\mathrm{MgO}-\mathrm{Al}_{2} \mathrm{O}_{3}-\mathrm{SiO}_{2}-\mathrm{H}_{2} \mathrm{O}$ ) with application to natural rocks. Contributions to Mineralogy and Petrology 145, 301-15.

White, R. W., Powell, R. \& Phillips, G. N. 2003. A mineral equilibria study of the hydrothermal alteration in mafic greenschist facies rocks at Kalgoorlie, Western Australia. Journal of Metamorphic Geology 21, 45568.

Zeh, A., Holland, T. J. B. \& Klemd, R. 2005. Phase relationships in grunerite-garnet-bearing amphibolites in the system CFMASH, with applications to metamorphic rocks from the Central Zone of the Limpopo Belt, South Africa. Journal of Metamorphic Geology 23(1), 1-17. 